\title{
SARS-CoV-2 Transmission Channels: A Review of the Literature
}

\author{
Ekram W. Abd El-Wahab MBChB MPH PhD, Safaa M. Eassa MBChB MPH DrPH, Mohammed Metwally MBChB MS PhD, \\ Husam Al-Hraishawi DVM MS, Sherif R. Omar MBChB DTM\&H MPH DrPH
}

\begin{abstract}
BACKGROUND The novel coronavirus SARS-CoV-2 is responsible for the current global pandemic. There is a concerted effort within the global scientific community to identify (and thereby potentially mitigate) the possible modes of transmission through which the virus spreads throughout populations.
\end{abstract}

OBJECTIVE Summarize the ways in which SARS-CoV-2 is transmitted and provide scientific support for the prevention and control of COVID-19.

EVIDENCE AQUISITION We conducted an extensive literature search using electronic databases for scientific articles addressing SARSCoV-2 transmission published from December 28, 2019 through July 31,2020 . We retrieved 805 articles, but only 302 were included and discussed in this review. The report captured relevant studies investigating three main areas: 1) viral survival, 2) transmission period and transmissibility, and 3) routes of viral spread.

DEVELOPMENT Currently available evidence indicates that SARSCoV-2 seems to have variable stability in different environments and is

\section{INTRODUCTION}

The COVID-19 pandemic is caused by severe acute respiratory syndrome coronavirus 2 (SARS-CoV-2).[1] The outbreak, attributed to an emerging virus, was first identified in late November 2019, in Wuhan, China. WHO declared the outbreak to be a Public Health Emergency of International Concern (PHEIC) on January 30, 2020, and recognized it as a pandemic on March 11, 2020. As of August 2, 2020, a total of 17,628,109 confirmed cases of COVID-19 have been reported in 213 countries and territories, resulting in approximately 680,354 deaths. More than 11,349,471 people have since recovered.[2]

Given the urgency surrounding the pandemic, scientific publications and news outlets are consistently publishing emerging evidence on the ways in which SARS-CoV-2 is transmitted. However, these initial findings need to be carefully interpreted and monitored. The objective of this report is to review the available scientific literature on viral propagation, the risk of transmission and the importance of bundled prevention measures.

\section{EVIDENCE AQUISITION}

We conducted an extensive literature search covering the COVID-19 pandemic (from December 28, 2019 through July 31, 2020) in

\section{IMPORTANCE}

Many questions remain unanswered regarding SARS-CoV-2's modes of transmission. More research is needed to debunk speculations being made about SARS-CoV-2 and fill in the gaps in knowledge regarding the behavior of the virus and corresponding necessary preventive measures. This review is a contribution to the ongoing efforts to understand and adapt to the demands of the COVID-19 pandemic. very sensitive to oxidants, such as chlorine. Temperature and humidity are important factors influencing viral survival and transmission. SARSCoV-2 may be transmitted from person to person through several different routes. The basic mechanisms of SARS-CoV-2 transmission person-to-person contact through respiratory droplets, or via indirect contact. Aerosolized transmission is likely the dominant route for the spread of SARS-CoV-2, particularly in healthcare facilities. Although SARS-CoV-2 has been detected in non-respiratory specimens, including stool, blood and breast milk, their role in transmission remains uncertain. A complicating factor in disease control is viral transmission by asymptomatic individuals and through what would otherwise be understood as innocuous human activities.

CONCLUSIONS This article provides a review of the published research regarding human-to-human transmission of SARS-CoV-2 and insights into developing effective control strategies to stop viral propagation.

KEYWORDS COVID-19, SARS-CoV-2, transmission, pandemics, microbial viability

the major electronic databases (ISI Web of Knowledge, PubMed, Medline, ScienceDirect, EMBASE, EBSCO, ProQuest, and Google Scholar), the websites of WHO, CDC and the Mayo Clinic, and preprint platforms (bioRxiv, medRxiv, SSRN and Qeios), with the search terms: ["2019-novel coronavirus" OR "2019 nCoV" OR SARS-CoV-2 OR COVID-19 OR "novel coronavirus"] AND [transmit* OR spread OR shedding OR pandemic OR outbreak OR contact OR droplet OR aerosol OR "respiratory trans" OR "air borne" OR fecal OR oral OR "blood borne" OR "ocular trans" ${ }^{\star}$ " OR eye OR conjunctiv* OR "contact lens" OR "vertical transmission" OR "mother to child transmission" OR breastfeeding OR sexual OR zoonotic OR animal OR "vector borne" OR household OR "solid waste" OR "waste water" OR "organ transplant*" OR hemodialysis OR nosocomial OR "healthcare worker" OR "hospital infection" OR tobacco OR travel* OR refugee OR migrant OR homeless* OR "mass gathering" OR prison* OR incarcerat* OR detention OR addict*]. (Note that enclosing a term or phrase with quotation marks in a websearch filters out all responses that do not include exactly that term or phrase, and the inclusion of an asterisk after a group of letters in a websearch broadens the search by including all words that begin with those same letters). A total of 805 studies were retrieved and exported to the reference manager EndNote X8 (Thomson Reuters, London). A total of 258 duplicate studies were removed. We included research articles, review articles and clinical trials, case reports, correspondence, and situation reports that were published in English. All titles and abstracts were screened for relevance and full texts of potentially eligible articles were reviewed. The information was organized according to three main subjects: 1) viral survival, 2) transmission period and transmissibility and 3) routes of viral spread.

\section{DEVELOPMENT}

Viral survival

Viability and stability on surfaces The high transmissibility of SARS-CoV-2 could be attributable to the greater environmental 
viability of this virus compared to other human coronaviruses. Van Doremalen[3] analyzed the aerosol and surface stability of SARS-CoV-2 and compared it with SARS-CoV-1, the most closely related human coronavirus, on a variety of surfaces commonly found in household and hospital settings (aerosols, cardboard, plastic, copper and stainless steel), and estimated the decay rates using a Bayesian regression model. In the experiment, van Doremalen attempted to mimic viral deposits from an infected person onto everyday surfaces in a household or hospital setting, such as through coughing or touching objects. The researchers used a high-powered machine (threejet collision aerosolizer) to generate tiny artificial particles $(<5$ $\mu \mathrm{m})$.

Stability on surfaces was evaluated by depositing $50 \mu \mathrm{L}$ of virus and recovering the inoculum by swabbing, whereas viability of the virus in all surface and aerosol samples was quantified by end-point titration on Vero E6 cells. Throughout the duration of the experiment (3 hours), SARS-CoV-2 remained viable and was detectable, albeit with a drop in infectious titer from $10^{3.5}$ to $10^{2.7} \mathrm{TCID}_{50}$ per liter of air. The virus was more stable on plastic and stainless steel (2-3 days) than on copper (4 hours) and cardboard (24 hours). Similarly, Kampf found that SARS-CoV-2 can remain infectious for 2-9 days on different types of materials.[4] However, these experimentally-induced particles that remained suspended in aerosols do not seem to simulate those distributed from a sneeze or cough from a COVID-19 patient and thus does not reflect a clinical setting. [5-8] Importantly, authors sampled the air for just three hours, meaning the virus could potentially remain viable in the air for longer. Moreover, the authors did not verify whether these viruses were still capable of causing the disease. In this context, the two tested viruses behaved in a similar manner, but why SARS-CoV-2 has greater transmissibility remains unclear.

It is probable that SARS-CoV-2-infected individuals are spreading the virus before showing symptoms and likely that SARS-CoV-2, being novel, is highly contagious in an immunologically-naive population.[9] This brings into question whether the control measures that were effective against SARSCoV-1 are equally effective when deployed against SARSCoV-2. Until we learn more about virus viability in a variety of settings and conditions, we have to consider all potential routes of transmission.

These studies provide key information about the stability of SARS-CoV-2. The findings may have important repercussions for medical workers as well as the public and suggest that people may acquire the virus through the air or after touching contaminated objects. SARS-CoV-2 is quite transmissible through relatively casual contact, making this pathogen very hard to contain. The virus can live on items we touch often every day-such as mobile phones, tablets, computer keyboards, door handles and elevator buttons - for just as long and thus these objects should be disinfected frequently. However, on copper surfaces, which contain natural antimicrobial and virucidal properties and have been shown together with silver and aluminum to inactivate microbes,[10] SARS-CoV-2 was able to survive for four hours.
Physical and chemical inactivation Pastorino evaluated the heating and chemical protocols for inactivating SARS-CoV-2 while processing respiratory samples exhibiting higher viral loads than droplets. A temperature of $60{ }^{\circ} \mathrm{C}$ for 60 minutes was sufficient to inactivate SARS-CoV-2 in low viral loads, while heating samples to $92{ }^{\circ} \mathrm{C}$ for 15 minutes was more effective in achieving a reduction of $6^{*} \log$ (viral load) highly loaded clinical samples.[11]

Alex Chin at the University of Hong Kong found that SARS-CoV-2 is persistently stable at a temperature of $4{ }^{\circ} \mathrm{C}$. The study showed the virus can stay viable at high levels at room temperature for 7 days (eliminated after 14 days), and will gradually abate at $27{ }^{\circ} \mathrm{C}$ over 24 hours or after 30 minutes at $56{ }^{\circ} \mathrm{C}$ or after 5 minutes incubation at $70^{\circ} \mathrm{C}$.[12]

Thus far, there is no direct evidence on the influence of ambient temperature and humidity on SARS-CoV-2 transmission, and the activity or behavior of the virus in different climatic conditions is still unknown.[13] During the winter season in the Northern Hemisphere, that is before March 22, 2020, 90\% of COVID-19 cases had been recorded in non-tropical countries with low temperatures and low humidity.[14]

Wang investigated the role of temperature and humidity in reducing SARS-CoV-2 viability. After fitting a regression model, they found that both high temperature and high relative humidity had a significant effect on the reproductive number $\mathrm{R}$. One degree Celsius increase in temperature and one percent increase in relative humidity lowered $\mathrm{R}$ by 0.0225 and 0.01158 , respectively. Although their results indicated that SARS-CoV-2 transmission may be reduced with the arrival of summer and rainy seasons in the northern hemisphere, it is still unclear whether these findings will hold true in extremely hot, extremely cold or extremely dry areas, since the threeday (January 21-23, 2020) average temperatures and relative humidity ranged from $-21{ }^{\circ} \mathrm{C}$ to $21{ }^{\circ} \mathrm{C}$ and from $47 \%$ to $100 \%$ humidity.[15]

Sajadi also found that temperatures $>32^{\circ} \mathrm{C}$ and high humidity influenced the spread of SARS-CoV-2, illustrating in their study that the virus has established significant community spread in cities and regions lying along a narrow east-west distribution, with consistently similar weather patterns $\left(5^{\circ} \mathrm{C}-11\right.$ ${ }^{\circ} \mathrm{C}$ and $47 \%-79 \%$ humidity).[16] This suggests that weather factors may affect the virus, particularly humidity and hours and intensity of sunshine. On the other hand, Marc Lipsitch of Harvard's T.H. Chan School of Public Health recently posted an analysis in which he concluded that warmer weather will "probably not" significantly slow the spread of the novel virus. [17]

A log-linear generalized additive model controlling for potential confounders was used to analyze the effects of temperature and relative humidity on daily new cases and daily new deaths of COVID-19 in 166 countries (excluding China) as of March 27,2020 , where higher temperatures and relative humidity were both negatively related to daily new cases and deaths. [18] Consistently, lower humidity was associated with a 6-fold increase in locally-acquired positive COVID-19 cases in Sydney during the early stages of the epidemic. 
Mecenas observed great homogeneity in a systematic review on effects of temperature and humidity on SARS-CoV-2's seasonal viability and transmissibility. Cold and dry conditions were potentiating factors for viral transmission, whereas warm and wet climates seem to reduce spread. They concluded that the lower the humidity and the drier the air, the smaller the aerosols that can stay suspended in the air for longer durations. On the other hand, when the air is humid, the aerosols become larger and heavier, thus settling on surfaces more quickly, leading to a decreased chance of infection through airborne transmission.[19]

Inactivation by biocidal agents has been studied extensively. For instance, experimental studies demonstrated that the virus can be efficiently inactivated by several surface disinfectants. Ethanol (62\%-71\%) reduced coronavirus infectivity by 2.0 $4.0 \log _{10}$ with an exposure time of one minute. Hydrogen peroxide $(0.5 \%)$ and sodium hypochlorite $(0.1 \%-0.5 \%)$ each cause $>3.0 \log _{10}$ reduction in viral titers within one minute. The virus can also be inactivated by 2-propanol (70\%-100\%), the combination of 2-propanol (45\%) with 1-propanol (30\%), formaldehyde $(0.7 \%-1 \%)$, glutardialdehyde $(0.5 \%-2.5 \%)$, and povidone-iodine $(0.23 \%-7.5 \%)$, all reducing its infectivity by $4 \log _{10}$ or more.[9] In another setting, sodium-dodecyl-sulfate and Triton-X100, when added to guanidinium thiocyanate-lysis buffers, resulted in a $6_{\log }$ reduction of virus in highly infectious clinical samples.[11]

The SARS-CoV-2 virus has been specifically tested for its ultraviolet (UV) susceptibility. Like many related coronaviruses, including the SARS coronavirus, SARS-CoV-2 was found to be highly susceptible to UV inactivation. For instance, UV-Cbased disinfection was found helpful in stopping the SARSCoV-2 virus from replicating.[20,21] A class of transparent conductors allowing for high levels of UV light to sufficiently kill the virus has been recently released for use in disinfecting public areas.[22]

Transmission period and transmissibility People infected with SARS CoV-2 can be contagious prior to the onset of symptoms, as many laboratory-confirmed cases were asymptomatic.[23-25] Asymptomatic carriers emerge as a new challenge for disease control. Moreover, post-discharge surveillance revealed that the duration of viral shedding may extend for more than one month after recovery and seroconversion.[26-28]

Early transmission dynamics showed the basic reproduction number, $\mathrm{R}_{0}$ of SARS-CoV-2 was 2.2 to 2.7,[29-31] although in other models it was calculated as 3.3[32] and 5.7.[33] The real-time reproduction number $\left(R_{t}\right)$ was consistent with $R_{0}$, albeit with variations in different countries: Italy (3.1); Spain (3.95); Germany (4.43) and France (6.56).[34] This implies that different mathematical approaches and assumptions may yield different results, and transmission dynamics may vary geographically.

\section{Routes of viral spread}

Respiratory droplets and aerosols SARS-CoV-2 is classified according to the US Centers for Disease Control and Prevention (CDC) as a respiratory virus, and is thus believed to be transmitted mainly through "respiratory droplets" when infected people sneeze, cough or talk. Like many respiratory viruses, including flu, SARS-CoV-2 can be spread in tiny droplets released from the nose and mouth of an infected person as they cough.[35] A single cough can produce up to 3000 droplets, and droplet diameters vary greatly (1-2000 $\mu \mathrm{m})$. [36] If enough pathogens are present in the droplets, they may be inhaled and spread to others. When airborne, the droplets' moisture quickly evaporates, leaving droplet nuclei. The size of the nuclei and whether they carry pathogens determine their infectivity. Humans can inhale particles containing pathogens with diameters of 2-10 $\mu \mathrm{m}$, which account for some 60\%$80 \%$ of droplet nuclei produced by coughing and sneezing, respectively.

The inhaled particles can then settle in the alveoli and cause infection. Droplet nuclei produced by coughing are equivalent to only about $5 \%$ of sneezing droplets (sneezing droplets spreading more effectively.) Unless a large number of pathogens are present in droplet nuclei produced from saliva, sneezing or coughing, it is unlikely that these actions are directly responsible for transmission.[37] The longest sneezing transmission distance was found to be $1.7 \mathrm{~m}$, and most of the droplets with particles of $0.36 \mu \mathrm{m}$ fell to the ground.[38] Larger particles carrying pathogens will thus settle and contaminate other objects, such as door handles, seats, public transport handrails, elevator surfaces, etc., which then pose the risk of indirect contact transmission.[37]

Assuming that inhaled particles $<50 \mu \mathrm{m}$ can settle in the nasal cavity, these particles would then account for $>95 \%$ of the droplet nuclei produced from sneezing and coughing. However, one study found that $99.99 \%$ of pathogens are carried by particles larger than $50 \mu \mathrm{m}$.[39] Apparently, viral transmission through droplets requires the infected person to eject a large number of pathogens to result in direct transmission. When there is no air flow interference, it takes about 30-60 minutes for $90 \%$ of the droplet nuclei carrying pathogens to disappear from the air. Droplet nuclei with a diameter $>4-8 \mu \mathrm{m}$ usually disappear within 90-120 minutes. With airflow, the droplet core disappears from the air faster.

These data were recently updated using spray droplet measurement systems and spray scan laser sheets to analyze droplet production from coughs and speech by measuring the droplet size distribution, trajectory, travel distance and velocity, and time spent airborne in relation to the level of ventilation.[40,41] In a study conducted by Lewis,[42] although large $(100-1000 \mu \mathrm{m})$ and small $(1-10 \mu \mathrm{m})$ droplets were produced during coughing, only small droplets appeared during speech. Droplets produced by sneezing coming from both the oral and nasal cavities were predominately large ones. These did not travel far before gravity bent their trajectory downward, falling on the ground within one second. On the other hand, droplets as small as $5 \mu \mathrm{m}$ took almost 9 minutes to reach the ground when produced at a height of $160 \mathrm{~cm}$. This finding has key implications for aerosol transmission of SARS-CoV-2.[42] Importantly, normal breathing did not produce any kind of droplets. Ventilation of spaces substantially diluted respiratory droplets, thus poorly ventilated and populated spaces could contribute to the spread of SARS-CoV-2. 
Available research suggests that bioaerosols generated directly through exhalations may spur SARS-CoV-2 transmission. This could help to explain why SARS-CoV-2 is so contagious and how asymptomatic and mildly infected people may fuel the spread of the virus. Airborne transmission is plausible since virus particles that were experimentally aerosolized could remain viable for up to 3 hours.[3] William Ristenpart, a professor of chemical engineering at University of California-Davis, stated that SARS-CoV-2 spreads primarily via aerosols emitted when people speak.[43]

People emit virus particles in a range of sizes including small droplets or fine particles, or "aerosols", that can be suspended in the air for hours and flow with air currents long enough to infect passersby.[44] Bourouiba, in a new model of respiratory emissions, stated that under the right conditions, peak exhalation speeds can reach up to $10-30 \mathrm{~m} / \mathrm{s}$. Liquid droplets from sneezes, coughs and even breathing are trapped in turbulent gas clouds, allowing them to travel $>7-8 \mathrm{~m}$, and linger in the air for minutes. Pathogens in the cloud could potentially reach air circulation systems inside buildings. The best defenses are the outdoors and open windows where air circulation or wind disperse and dissipate the clouds reducing droplet concentrations.[45] However, the author did not look at gas clouds of patients infected with the SARS-CoV-2 virus.

A recent study found live SARS-CoV-2 particles to be widely distributed in the air and on object surfaces in the intensive care unit (35\% of samples) and general ward $(12.5 \%$ of samples) of the Huoshenshan Hospital in Wuhan, China. SARS-CoV-2 aerosols were most concentrated near and downwind to patients' rooms. These results confirm that SARS-CoV-2 aerosol exposure poses risks, and that the maximum transmission distance of SARS-CoV-2 aerosol might be 4 meters.[46] In a hospital in Nebraska, USA, viral RNA was found in two-thirds of air samples collected in isolation rooms for severely ill COVID-19 patients and in a quarantine facility housing those with mild infections. Viral RNA was also isolated from surfaces on ventilation grates.[47] In another study, viral RNA from SARS-CoV-2 was found in a number of locations, including department stores.[48] Although the three aforementioned reports did not confirm whether the collected aerosols are capable of infecting new cells, the data suggest that viral aerosol particles are produced by infected individuals, even in the absence of cough or sneezing.

On the other hand, there are reports from settings where no SARS-CoV-2 RNA was detected in air samples collected $10 \mathrm{~cm}$ in front of symptomatic COVID-19 patients who were breathing, speaking and coughing.[49-51] It is important to note that RNA detection in environmental samples based on PCR assays is not necessarily indicative of viable, transmissible virus.

Airborne transmission of SARS-CoV-2 may be possible in certain circumstances in which aerosol-generating procedures (AGPS) are performed, such as respiratory tract suction before or after intubation, nebulizer treatment, manual ventilation, oxygen mask manipulation, bronchoscopy, chest compression or cardiopulmonary resuscitation, tracheostomy, or disconnecting a patient from a ventilator.[52] Further studies are needed to determine whether it is possible to detect the COVID-19 virus in air samples from wards where no therapeutic procedures that generate aerosols are ongoing.

Active SARS-CoV-2 has been detected in patients' saliva by cell culture, although serial monitoring over time showed declining viral load.[53] Saliva can be discharged through coughing and can contain nasopharyngeal or lung secretions. When there is no coughing or in patients with no symptoms, SARS-CoV-2 can still be transmitted directly or indirectly through saliva.[35,53,54]

On March 29, 2020, WHO stated that aerosol transmission of the virus needs further evaluation and confirmation, and the number and distribution of SARS-CoV-2 in droplet nuclei ejected by coughing or sneezing have yet to be confirmed by research.[52] It is crucial to know the concentration of SARSCoV-2 particles which would result in a significant likelihood of infection. The duration of exposure necessary to inhale enough virus to cause infection is likely also an important factor. Under favorable combined conditions of airflow, humidity and temperature, an infectious dose of the virus might build over time. We should acknowledge the difficulty of obtaining data in this context since deliberately exposing people and measuring the infection rate at different doses would be unethical.

Evidence-based hypotheses support the possibility of SARSCoV-2 airborne transmission due to its persistence in aerosol droplets in a viable and infectious forms. Based on available knowledge and epidemiological observations, it is plausible that small particles containing the virus may diffuse in indoor environments covering distances up to 10 meters from emission sources.[55,56] This explains the anomalous COVID-19 outbreaks in northern Italy, ranked as one of the most polluted areas in Europe and characterized by high particulate matter concentrations.[57]

On July 6, 2020, more than 200 scientists submitted an open letter to WHO warning about airborne transmission of SARSCoV-2 via aerosols and urging the organization to recognize the risks. On July 9 , WHO responded with an update in which it acknowledged with hesitation the growing evidence of airborne spread of the disease.[58]

Contact transmission Contact transmission of SARS-CoV-2 can occur through indirect contact with fomites in the immediate environment around the infected person or with commonly touched surfaces of objects potentially contaminated by landed patient secretions (nasal cavity, oral cavity, conjunctiva, etc.), such as door knobs, seats, elevator surfaces, faucets, public transport handrails, computer mice, trash bins, etc. Susceptible individuals can then be infected through the nasal mucosa or conjunctiva when touching the nostrils or rubbing the eyes. $[59,60]$ It is reported that SARS-CoV-2 RNA has been detected on hospital door handles in Shandong and Guangzhou, China. [39] In a study at the University of Nebraska Medical Center, besides medical equipment, about $80 \%$ of frequently touched miscellaneous personal items tested positive for SARS-CoV-2 RNA by reverse transcription polymerase chain reaction (RT-PCR). These included exercise equipment, personal computers, tablets, cellular phones, reading glasses, remote controls for in-room TVs, toilet seats, room surfaces, tables, bed rails and window ledges.[47] A case report published 
by the CDC suggested SARS-CoV-2 transmission may have occurred via contact with contaminated surfaces. In that case, a SARS-CoV-2-infected asymptomatic person attended a church service and transmitted the disease to another person who sat in the same seat later that day. Nevertheless, it could not be ascertained whether the virus was contracted via a contaminated surface or through lingering aerosol.[25]

Since SARS-CoV-2 could remain viable for several days on surfaces such as cardboard, plastic and steel,[3] concerns have been raised about packages, shipments and groceries. [61] Although these items are likely safe, it is possible that an infected person could unknowingly deposit a significant amount of contaminant on them. Thus, it is advisable to wipe down these items using approved disinfectants.[61] Nonperishable items with same-day delivery can be left to sit for 12-24 hours at room temperature to minimize risk. Given current epidemiological data, it is possible that contact with SARS-CoV-2-contaminated surfaces may be one of its main transmission routes, although controversy remains about how much and for how long SARS-CoV-2 can survive on different contaminated surfaces.

Fecal-oral transmission Early in the outbreak, fecal-oral transmission was flagged as a possible route for SARSCoV-2 spread.[62] The angiotensin-converting enzyme 2 (ACE2) receptors used by SARS-CoV-2 to enter cells are highly expressed in lung alveolar type 2 cells and in upper esophageal and stratified epithelial and absorptive enterocytes in the ileum and the colon.[63-66] SARS-CoV-2 was detected in the intestinal tissues of animals exposed to the virus. The virus was also detected in biopsy specimens and stool, even in patients discharged after recovery, which may at least partially explain reported gastrointestinal symptoms,[67,68] potential recurrence, and transmission of SARS-CoV-2 from persistently shedding patients.[69,70]

Recent evidence has confirmed the presence of SARS-CoV-2 in fecal specimens from COVID-19 patients, and live virus has been cultured from stool samples.[71-74] Digested sputum may represent the origin of the virus in stool.[75] However, viral RNA concentration in anal swabs was higher than in the blood,[76] suggesting that the virus might replicate in the digestive tract. Contamination of hands, food and water may occur via contact with fecal content and may cause infection by invading the oral cavity and respiratory tract.[69,77-80] Chen recorded viral shedding at multiple time points in stool specimens. [81] Although all specimens were not equally consistent with oropharyngeal swabs, stool samples tested positive for SARSCoV-2 RNA in 28 (66.7\%) patients, of whom 18 (64.3\%) remained positive for fecal viral RNA after the virus had cleared from their nasopharynxes. The average duration of viral shedding from feces after negative conversion in pharyngeal swabs was 7 days, although in some cases, this extended up to 4-5 weeks.[70] Interestingly, detection of SARS-CoV-2 RNA in stool was not linked to concurrent gastrointestinal symptoms, illness severity or particular demographic, clinical, laboratory or radiologic findings.[81]

Similarly, Wu verified the presence of SARS-CoV-2 RNA in 55\% of fecal specimens of patients with a positive oropharyngeal swab (RT-PCR).[82] Considering the infectiousness of SARS-CoV-2 isolated from stool samples, three studies have successfully cultured SARS-CoV-2 with a typical morphology from stool specimens in Vero cells.

The aforementioned evidence affirms the potential for fecal-oral or fecal-respiratory transmission of SARS-CoV-2, [71,83,84] even after patients have tested negative with RT-PCR oropharyngeal swab. Accordingly, treated patients who meet discharge criteria with a negative oropharyngeal swab should be advised they may still spread the disease via the fecal shedding route. Setting a negative fecal viral RNA test as part of the criteria for patient discharge is thus warranted.

Ocular transmission (Conjunctiva, tears, contact lenses) Tears are one of the body fluids that can transmit SARS coronavirus. [85] Although ACE2 proteins are widely distributed in many organs of the body (skin, lymph nodes, thymus, bone marrow, spleen, liver and brain),[63] their expression in conjunctival epithelia is yet to be confirmed. Lu stated that the route of conjunctival COVID-19 infection and tear transmission cannot be ignored, as unprotected ocular exposure (while fullygowned with a protective suit and N95 respirator) was thought to be responsible for nosocomial infections in the Wuhan Fever Clinic.[86,87] Ocular fluid from SARS-CoV-2-infected patients was found to contain the virus. This occurred early in the disease course and was confirmed by viral RNA detection.[88] Similar case presentation and findings were reported by other scholars.[89-91] These findings highlight the importance of hygienic measures and appropriate use of personal protective equipment (PPE), because ocular mucosa could be both a site of virus entry and a source of contagion.

Liang and Wu detected SARS-CoV-2 RNA by RT-PCR in the conjunctival sac of 37 COVID-19 patients, of whom 3 had conjunctival congestion/inflammation. The viral load of conjunctival sac secretion was relatively low and proportional to the severity of the disease,[92] suggesting that ocular symptoms commonly appear in patients with severe pneumonia.[93] Reports of typical signs and symptoms from 55,924 laboratory-confirmed cases showed that conjunctival presentation was found in $0.8 \%$, and it was unclear whether it was an initial or a concurrent symptom.[70,94,95] Indeed, SARS-CoV-2 may cause tears and conjunctivitis in the case of direct inoculation, migration of an upper respiratory tract infection, or hematogenous involvement of the lacrimal gland. [96]

In a prospective interventional case series study, Xia collected tears and conjunctival secretions at an interval of two-three days and tested for SARS-CoV-2 by RT-PCR. They found that tears and conjunctival secretions were positive for viral RNA only if COVID-19 pneumonia patients had conjunctivitis. However, isolation of the virus was unsuccessful. These results suggest that SARS-CoV-2 does not replicate in conjunctival epithelia and that ocular transmission is unlikely.[97] On the other hand, when tear sampling time points covered two weeks of active infection in an attempt to provide a good representation of the full disease course, all tear samples including those from patients with ocular manifestations, showed negative results, although nasopharyngeal swab samples continued to test 
positive. Importantly, tear samples were incubated in cell lines four days before RNA extraction to rule out the possibility of false negative RT-PCR if a cytopathic effect could be observed. This again suggests that the risk of transmission through tears regardless of the phase of infection is likely low.[98]

Contact lenses have been raised as a potential concern for increased risk of exposure to the virus, although no evidence of contracting COVID-19 infection through handling contact lenses has been reported thus far. However, as contacts can cause eye irritation, wearers touch their faces when putting on and removing contacts, and may rub their eyes more often, all of which puts them at a higher risk for acquiring infection. Contact lens wearers may wish to opt to use spectacles, instead.[99]

Mother-to-child transmission Given the changes to physiology and immune function during pregnancy, pregnant women might face greater risks of being infected by SARS-CoV-2. Many diseases can be transmitted vertically by the mother-to-child route. Although mother-to-child transmission of SARS-CoV-2 still requires more evidence before it can be confirmed, there have been cases that point to the possibility of this route. Evidence for such transmission was based on clinical and laboratory findings, particularly elevated IgM (immunoglobulin M) antibody values in blood drawn from neonates following birth,[100-102] or positive neonatal nasopharyngeal swabs for SARS-CoV-2 RNA by RT-PCR.[103] Positive IgM results with their inherent challenges of false positivity or cross reactivity with other congenital infections (sensitivity and specificity of $70.2 \%$ and $96.2 \%$, respectively) are not definitive evidence of in utero infection. In many cases, infection in early infancy may have occurred due to postnatal contact with COVID-19positive parents or caregivers.[104]

A meta-analysis of 21 articles, which included 92 neonates born to 90 mothers infected with COVID-19, found no differences in the clinical characteristics of pregnant women and non-pregnant COVID-19 patients. Maternal COVID-19 infection has caused higher incidence of fetal distress and premature labor, although vertical transmission was rare (4 out of 86 neonates tested positive for the virus by RT-PCR). [105] An additional report of 10 pregnant women infected with COVID-19 resulted in similar findings: that is, while no vertical transmission of SARS-CoV-2 occurred after delivery, perinatal infection had produced adverse effects on newborns including intrauterine fetal distress, premature labor, respiratory distress, thrombocytopenia and abnormal liver function, and even death. [106]

The cause of such neonatal illness or death remains unclear, and the possibility of false negative PCR tests cannot be ruled out. More specimens, including umbilical cord blood, amniotic fluid, gastric fluid, stools or anal swabs from the neonates should have been collected to optimize detection of viral RNA. Furthermore, the placenta tissue should have been examined for possible placental inflammation caused by viral infection. In any case, when these samples were considered in further studies, all tested negative for SARS-CoV-2.[107-110] This suggests that placental shedding and mother-to-child transmission is unlikely for this virus, probably due to low maternal viremia. [84] The criteria that should be used for definitive diagnosis of vertical SARS-CoV-2 transmission remain unclear. One suggestion is a neonatal nasopharyngeal swab positive for virus within one to two hours of birth and before contact with an infected individual, and an elevated IgM level for the virus in cord blood. Although clinical characteristics of COVID-19 in pregnant women were similar to infected non-pregnant women, the case fatality of COVID-19 among pregnant women was $25 \%$. The related complications included acute respiratory distress syndrome, disseminated intravascular coagulopathy, secondary bacterial pneumonia, renal impairment and sepsis. $[105,111,112]$

It is noteworthy that in all previous reports, pregnant women were recruited in their third trimester, and thus the possibility of intrauterine vertical transmission during the first or second trimester cannot be ascertained.[113] The impact of rubella infection, for example, increases two-fold in the first trimester compared to the second trimester.[114] Moreover, all infected pregnant women underwent caesarian delivery, thus whether normal labor or uterine contractions increase the risk of motherto-child transmission has yet to be clarified.[112,113,115] In a retrospective study, vaginal delivery was described as carrying a low risk of intrapartum SARS-CoV-2 transmission to the newborn, although one newborn tested positive after a vaginal delivery.[116] Several cases of uncomplicated labor and vaginal delivery in women with COVID-19 were reported.[117,118]

Breastfeeding Breast milk provides protection against many illnesses. Currently, it is unclear whether SARS-CoV-2 can spread via breast milk, but an infected mother can transmit the virus to her infant via respiratory droplets during breastfeeding. [111] In limited studies, SARS-CoV-2 has not been found in breast milk, [108] but fragments of the viral RNA were detected by RT-PCR in a few breast milk samples of infected mothers although the isolated virus was not viable.[119] This does not rule out the possibility that mothers with COVID-19 could spread the virus via breast milk.

Confirmed or symptomatic mothers under investigation should take all possible precautions to avoid spreading the virus to their infants. When two mothers with COVID-19 who contracted the infection in the post-partum period breastfed without a mask, their newborns tested positive for SARS-Cov-2.[116] As per WHO recommendations, mothers with suspected or confirmed COVID-19 are encouraged to initiate or continue breastfeeding. [120] Whether mothers decide to express milk or to breastfeed directly, strict hygiene measures should be followed including face masks, hand washing and use of a breast pump.[121]

Sexual transmission Without a doubt, SARS-CoV-2 has implications for sexual and reproductive health.[122] Whether SARS-CoV-2 is sexually transmitted is largely irrelevant to the risks of having sex with someone who is infected. Early in the pandemic, SARS-CoV-2 was thought unlikely to be spread through sexual intercourse, according to a study that found no molecular evidence of SARS-CoV-2 in collected semen samples[123] and testicular biopsy specimens[124] from 34 Chinese men with mild to moderate COVID-19, one month after diagnosis. Moreover, Cui did not detect any SARSCoV-2 RNA in vaginal swabs of 35 COVID-19-positive female patients and found no evidence of sexual transmission to their 
male partners.[125] More recently, 6 of 38 semen samples of COVID-19-infected men tested positive for SARS-CoV-2. Two of these samples were from patients who recovered. [126] However, since then, the virus has been found in feces, saliva and mucous, $[39,53,54]$ and the virus may be transmitted through anal or oral sex.[127] On the other hand, Wang provided bioinformatics evidence that human testes may be highly vulnerable to SARS-CoV-2 infection since ACE2 and transmembrane serine protease 2 (TMPRSS2), both of which act as receptors for SARS-CoV-2, are found in high numbers in human testicular tissue.[128] These findings provide potential clues for further investigations. Collectively, SARS-CoV-2 can be seeded in the male reproductive tract, and sexual transmission might contribute a critical proportion of overall viral propagation.

Zoonotic transmission COVID-19 is a zoonotic disease, whose spread was accelerated by modern human transportation and crowded urban environments, as well as through nosocomial transmission once severely-ill patients were hospitalized. [129-131] Little is known about the presumed animal reservoir. Preliminary reports based on the codon usage and originunknown homologous recombination of the spike glycoprotein suggested snakes as the possible wildlife source of the novel coronavirus.[132] However, RNA analysis revealed the virus to be most closely related to a coronavirus isolated from horseshoe bats (CoV RaTG13) living in Yunnan Province caves.[133-143]

Horseshoe bats are maintenance hosts for SARS-related coronaviruses, and SARS-CoV-2 may have emerged in a similar way through sequential genetic recombination events prior to spillover into an intermediate host, thus qualifying as zoonotic transmission.[129,144,145] Epidemiological evidence indicated that several episodes of zoonotic transmission occurred in late November 2019 at a Wuhan city wholesale market, where live wild animals including snakes, bats, marmots, deer and some game animals were illegally traded. $[129,146]$ Frequent human-animal interactions and low levels of environmental biosecurity in rural communities in southern China were identified as risks for zoonotic disease emergence. [147] Future in-depth research on specific risk factors will help tailor more fine-tuned risk mitigation strategies to reduce threats of emerging zoonoses.

There have been a few reports of infected pet dogs,[148,150] cats[151,152] and other domesticated animals.[148,152,153] However, there is currently no evidence of SARS-CoV-2 spreading from humans to pets or vice versa. Indeed, SARSCoV-2-positive dogs on RT-PCR had negative culture and serological tests, suggesting that the virus was unable to reproduce even when the best possible medium was provided. In one study, the COVID-19-positive dog never seroconverted to create antibodies against the virus, suggesting a weak infection not capable of eliciting an immune response and that the dog was never contagious to other pets or people. This means that the risk of pets serving as a source for SARS-CoV-2 infection, or for pets catching the disease from humans, must be extremely low. Research is being planned to better understand the risks and consequences of SARS-
CoV-2 infections in domestic animals. As part of the planned research, pet owners will be surveyed for particular interactions or behaviors that may contribute to the spread of the virus from humans to animals. Until we learn more, COVID-19-positive pet owners should exercise caution and appropriate physical distancing to keep their pets safe. Contact with pets in regard to kissing, petting or snuggling, sharing food, bedding, towels or dishware should be restricted.[154,155]

Air conditioning cooling systems New research suggests that air conditioning (AC) may circulate infectious droplets containing SARS-CoV-2. In fact, air conditioning has always had the ability to influence virus circulation, but concerns for SARS-CoV-2 are extreme given the great susceptibility of the population-atlarge to the virus and the current lack of a vaccine. An outbreak of COVID-19 in an air-conditioned restaurant in Guangzhou, China, involved nine persons in three family clusters. The infection was transmitted by a symptomatic index case at a table that was located in front of an AC unit to people at the same table as well as to others at a neighboring table. Although the six smear samples from the air conditioner intake and outtake hose all tested negative for SARS-CoV-2 as confirmed by RT-PCR, virus transmission in this outbreak cannot be explained by droplets alone. The scenario was consistent with droplet transmission prompted by the direction of the AC airflow, since lower concentrations of adrift aerosols at greater distances were insufficient to cause infection in other parts of the restaurant.[156]

AC systems may pose the same danger in home settings particularly in the case of central cooling units. Opening windows rather than using $A C$ would allow better air exchange and minimize viral spread.[157] In restaurants and banquet halls, it is crucial to increase the distance between tables and improve temperature-monitoring and ventilation surveillance. Ceiling fans with upward airflow rotation combined with upperair ultraviolet germicidal irradiation (UVGI) disinfection systems can be utilized.[158]

Household clusters Family clustering has been an important factor in SARS-CoV-2 transmission.[75] The secondary transmission rate among cohabiting family members and close contacts is highly variable $(5 \%-100 \%),[26,30,31,159]$ and transmission is mainly through respiratory droplets or through close contact. Cohabiting children (<20 years) are 4 times less likely than older adults ( $\geq 60$ years old) to catch SARS-CoV-2 with no risk differences by sex.[160] Variations in the clinical manifestations of the disease can occur across secondary cases. Asymptomatic carriers may remain asymptomatic, develop mild symptoms or even develop severe COVID-19.[24,160-167] Given that the viral loads of symptomatic and asymptomatic patients are similar,[168] silent patients (asymptomatic or minimally symptomatic) have high transmission potential and can still infect others. Moreover, transmission may occur early in the course of infection during the incubation period, $[24,160,166,167,169]$ which substantially impedes any potential of curbing the ongoing pandemic. This highlights the importance of epidemiological investigation of family-associated incidence rates, close contact tracing and longitudinal surveillance. Silent patients should be subjected 
to isolation and continuous reassessment by virus-specific nucleic acid tests.[161,162,166,169]

Infected children have been identified largely through contact tracing in households of adults.[170] A recent study of 65,000 youngsters found that those between the ages of 10 and 19 years are capable of spreading SARS-CoV-2 within households just as effectively as adults.[171] SARS-CoV-2 transmission can be particularly efficient in crowded, confined indoor spaces such as homes and workplaces where transmission rates can reach as high as 43\%.[172-175]

Foodborne transmission Currently foodborne exposure to SARS-CoV-2 is not believed to be a route of transmission. $[75,176]$ Because most initial cases had visited a wet market in Wuhan selling various exotic live animals, misinformation had circulated about the possibility of contracting SARS-CoV-2 if someone had eaten bats or bat soup. The mode of transmission became clearer after an explicit outbreak investigation that pointed to exceptionally wide contamination of a seafood market by bat excreta.[177]

Several factors could make transmission of SARSCoV-2 through food less likely, even if the virus is present on food: i) cooking at least $60{ }^{\circ} \mathrm{C}$ usually kills viruses in meat and animal tissue, while it is certainly possible that transmission could occur if someone prepared a bat for a meal or consumed it undercooked; ii) unlike bacteria, viruses cannot grow inside food; iii) because of the poor stability of SARS-CoV-2, it cannot survive for long on surfaces and would be expected to dwindle with time if it accidently contaminated foodstuffs; iv) unlike other enteric viruses (norovirus, rotavirus, astrovirus or hepatitis A virus), SARS-CoV-2 has a different structure and cannot survive in the acidic stomach media;[178] v) moreover, food safety measures that are already in place to prevent foodborne illness reduce the transmission of any virus particles through food.[178,179]

Waterborne transmission SARS-CoV-2 has not been detected in drinking water but was found in untreated wastewater. [180] As we pointed out earlier, SARS-CoV-2 nucleic acid has been found in urine and fecal matter of COVID-19 patients $[67,73,74,77,181]$ and the virus was successfully cultured from some specimens.[71,72] While data are limited, it is unclear whether virus found in feces may be capable of causing COVID-19. There has not been a confirmed report of the virus spreading from feces to humans. While plausible, it is not yet certain how well the virus is able to survive in water and wastewater, or whether a person exposed to untreated wastewater or sewerage can contract the infection. SARSCoV-2 may potentially enter wastewater systems through nasal secretions (e.g. due to the blowing of one's nose and subsequent flushing of tissues). Similar coronaviruses have persisted in water, urine, feces and wastewater for periods up to 2 days at $20{ }^{\circ} \mathrm{C}, 4$ days at $22{ }^{\circ} \mathrm{C}$ and 14 days at $4{ }^{\circ} \mathrm{C}$, in diarrheal stool samples with an alkaline $\mathrm{pH} .[183,184]$ However, conventional wastewater treatment methods adopted in most municipal drinking water plants that use filtration and disinfection should remove or inactivate any virus, including SARS-CoV-2.
As enveloped viruses, human coronaviruses have been shown to be more sensitive to chlorination, oxidant disinfection and ultraviolet light than other viruses with protein coats.[185] Transmission of the virus through properly designed and maintained sewage systems is a remote possibility. Beyond 'business as usual' no SARS-CoV-2-specific modifications are required.[180] Existing standard practices of wastewater treatment plant operations still apply and should be adequate in managing transmission risks to wastewater workers. It is important to dispose of greywater in drains connected to a septic system, sewer or in a soakaway pit. The latter should be fenced off within the health facility grounds to prevent tampering and to avoid possible exposure in case of overflow.[185] Recreational water is another concern, although no reports have been made of SARS-CoV-2 transmission through the water in pools or in water play areas.[186] Proper operation, disinfection and maintenance of these facilities should inactivate the virus in the water.[180]

Solid waste The COVID-19 pandemic is generating tons of medical waste and used gear contaminated with bodily fluids or other infectious materials. There is no evidence that direct, unprotected handling of health care or municipal solid waste has resulted in SARS-CoV-2 transmission.[185] Medical waste generated during COVID-19 care can be treated and safely disposed of the same way as regular medical waste.[187] Discarding medical waste carelessly into the environment might result in severe consequences, particularly surface and fresh water pollution. Care should be taken to limit direct exposure to solid waste using best management practices. Waste management operators working with very limited safety equipment such as scavengers and waste-pickers are at great risk of infection.[187]

Vector-borne transmission Although SARS-CoV-2 can be found at low levels in blood, transmission via insect bite remains a remote possibility until proven otherwise.[188] The situation is under surveillance and monitoring by the American Mosquito Control Association.[189]

There is no evidence to support that SARS-CoV-2 can be vector borne. Scientists are assessing the potential risk that vectors like mosquitoes pose in SARS-CoV-2 transmission. Members of Coronaviridae (SARS and MERS) are not transmitted through blood-feeding insects (mosquitoes, ticks, sandflies). The capacity of SARS-CoV-2 to infect and be transmitted by three widely distributed species of mosquito (Aedes aegypti, Aedes albopictus and Culex quinquefasciatus) has been experimentally investigated and the results showed that the virus is unable to replicate in these mosquitoes and therefore cannot be transmitted to people.[190]

Blood-borne transmission Nucleic acid from SARS-CoV-2 has been detected in many non-respiratory specimens including blood.[73,76,84,181] Although the role of blood in SARS-CoV-2 transmission remains uncertain, the risk merits caution and has resulted in some challenges to usual blood donation services. [191-193] The viral load peaks in the second week, but it is unknown if viremia occurs in pre-symptomatic or asymptomatic infection. $[193,194]$ The median duration of the virus in serum 
was 16 days and correlated with disease severity and patient age.[73,76] Generally, respiratory viruses are not transmitted through blood. The potential for SARS-CoV-2 transmission through blood or blood derivatives appears low since no transfusion-transmitted infection has been reported for SARSCoV-2 in recipients of platelets or red blood cell transfusions from donors diagnosed with SARS-CoV-2 or for the related coronaviruses SARS-CoV and MERS-CoV (the receptors did not develop COVID-19-related symptoms nor did they test positive for SARS-CoV-2).[195,196] Importantly, SARS-CoV-2 has been shown to attack the 1-beta chain of hemoglobin and capture the porphyrin to inhibit human heme metabolism. This diminishes hemoglobin binding capacity to oxygen, triggering resistant hypoxia coupled with very rapid multi-organ collapse in COVID-19 patients.[197]

Several studies have investigated pathogen inactivation and reduction technologies (PRTs) to completely eradicate the potential risk of coronavirus transmission via blood or blood products.[192] Since February 10, 2020, Wuhan Blood Center and all blood banks in Hubei province have tested blood donations for SARS-CoV-2 RNA.[192] Plasma samples from this bank that were positive for viral RNA from four asymptomatic donors were screened in real time and retrospectively back to January 25, 2020.[198] The European Center for Disease Prevention and Control (ECDC)[199] and American Association of Blood Banks (AABB)[200] conducted a rapid risk assessment of the SARS-CoV-2 outbreak and its impact on blood safety. In this context, they established a precautionary 21-28 days deferral of donation after potential exposure to a confirmed case, resolution of symptoms and completion of therapy in patients with confirmed COVID-19, or in those recently returned from an outbreak area.[199]

Apart from taking body temperature, screening questions for symptoms or potential exposure, active post-donation information gathering, and recalling and tracing infected donors, the ECDC, AABB, FDA and CDC do not currently recommend any specific measures for blood collection and testing protocols, since the risk for transfusion transmission of SARS-CoV-2 is still theoretical.[192] However, the safety of these actions is questionable in the face of unknown risk. [193] The New York Blood Center is closely monitoring the COVID-19 outbreak.[201]

Organ transplantation There is a risk of donor-derived SARSCoV-2 infection, either from living or deceased donors. [202] The ECDC has recommended SARS-CoV-2 testing for epidemiologically at-risk potential organ donors.[203] Transplant recipients are at high risk of infection from viruses since they require immunosuppressants. Considering the previous responses to similar viruses, SARS-CoV-2 may induce severe consequences in recipients. They are anticipated to have more intense and prolonged viral shedding, with potential secondary impacts on contacts and health care workers. Nevertheless, preliminary evidence from an Italian transplant center in Lombardy showed that immunosuppression did not increase the risk of severe COVID-19 disease. However, it was suggested that precautions were still merited, as severe clinical manifestations could be triggered by reactive innate immune responses.[204] On the other hand, kidney transplant patients with COVID-19 in London evolved to serious stages and the disease was associated with poor outcomes.[205] As more information surfaces, these risks require further clarifications before we are capable of drawing more solid conclusions.

To avoid severe consequences of SARS-CoV-2 infection on both the transplant community and the contacts of transplant patients, the American Society of Transplantation has put forward interim recommendations. Living donors are required to avoid disease outbreak areas for at least 14 days before donation and are monitored for symptoms and exposure history.

A 14-day deferral for elective organ donation is warranted for asymptomatic living donors with a recent history of travel to disease transmission areas or exposure to a person with known or suspected COVID-19. Deceased donors with known active COVID-19 are to be denied, whereas deceased donors with epidemiologic risks but without history of fever or respiratory illness or donors who have recovered from COVID-19 in the past are carefully considered for organs other than the lungs or intestine. Isolation procedures should be applied if a transplant is performed during a potential incubation period or in a country with endemic circulation of SARS-CoV-2. As more information becomes available, procedures related to transplantation must be updated.[202,203]

Hemodialysis Hemodialysis patients are in mandatory congregate settings, which compounds risk. Dialysis centers have become far more dangerous as SARS-CoV-2 spreads rapidly in the community. Several studies reported maintenance hemodialysis patients who contracted SARSCoV-2 infection, although the transmission could not be traced to the hemodialysis process.[206,207]

To anticipate this challenge and provide evidence-based guidance to patients, healthcare professionals and dialysis facilities, the American Society of Nephrology established a COVID-19 Response Team in conjunction with the CDC. [208,209] Preventive strategies must be implemented to minimize the risk of widespread dissemination of SARSCoV-2 in dialysis facilities, including education of staff and patients, careful disinfection, early recognition and screening for COVID-19 and separation of infected or symptomatic from non-infected patients.[210-212] Some dialysis organizations employ cohort models to identify epidemiologically at-risk patients and symptomatic or COVID-19-positive patients, transferring them to different facilities.[210]

Nosocomial transmission Many confirmed COVID-19 patients have been infected in healthcare facilities.[213-216] Based on a meta-analysis of 4 studies, the proportion of nosocomial infection with SARS-CoV-2 has been quite high, accounting for $44 \%$ of patients with COVID-19.[217] Indeed, early in the epidemic, hospital personnel did not know enough about the virus to take proper precautions, leading to inattentive prevention and control actions. Moreover, patients admitted to hospitals did not take any precautions or personal protection. Many unsuspicious COVID-19 cases were initially nursed in non-dedicated multi-bed wards, mingling and sharing common facilities with other patients.[218] 
Appropriate hospital control measures have been able to prevent nosocomial SARS-CoV-2 transmission. Contact tracing and surveillance did not result in COVID-19 cases among hospitalized patients or health care workers when a vigilant integrated infection control strategy was in place.[49,218-221] Influencing patient behavior to encourage them to take droplet and contact precautions, and applying social distancing within hospitals have been equally important in reducing nosocomial spread.[219] Interestingly, high-flow oxygen therapy $\geq 6 \mathrm{~L} / \mathrm{min}$ with a simple facemask posed a low risk of aerosol generation and did not result in secondary transmission[219] due to limited air leak through the side vents,[222,223] hence the neighboring patients were safe if they were kept at least one meter from the index patient. To increase safety during non-invasive ventilation, a helmet can be used as an interface if connected to the ventilator to avoid aerosolization.[224]

The "eagle-eyed observer" is another promising endeavor for minimizing SARS-CoV-2 nosocomial infection. In this context, an on-duty observer remotely monitors medical staff in real time and instructs for instant correction.[225,226] As a proactive infection control tool, this provides immediate solutions in negative pressure isolation wards at three stages (before medical worker entry, while in ward, and after leaving the isolation ward).

Health-care workers SARS-CoV-2 mimicked the 2003 SARS epidemic in producing alarming infection rates among healthcare workers (HCWs).[227,228] The virus attacked 2.0\%$29.0 \%$ of responding HCWs in China, Italy, Spain, USA and UK.[219, 229-232] Although some acquired the infection in the community, most contracted SARS-CoV-2 at their workplaces while providing direct patient care. Despite awareness of the potential of aerosol transmission through various therapeutic activities, inevitable exposure often occurred while performing AGPs.[219,229-232] HCWs have been therefore required to wear a full set of PPE and an N95 mask or equivalent gear while performing an AGP.[233] Of note, PPE could itself be a source of airborne contamination. In fact, Liu at Wuhan University studied SARS-CoV-2 aerodynamics in Wuhan hospitals and found that it can be resuspended in the air when HCWs remove their PPE, clean floors and move through infected areas.[48] $\mathrm{HCW}$ should therefore receive continuous training on proper hygiene measures and PPE use.[49,221,234] Although access to PPE is prioritized for HCWs, shortages or equipment that was not up to standards was described in many settings.[234] WHO is working with governments, industry and the Pandemic Supply Chain Network to boost production and secure sufficient PPE.[235]

According to some reports, HCWs were more likely to get SARS-CoV-2 in the community, yet there have been few scientific reports specifically looking into this aspect.[236,237]

Travel The COVID-19 pandemic has imposed a global shutdown of borders, including international air travel.[238] Travel restrictions go beyond border control, as entry thermal and syndromic screening for all incoming travelers, a 14-day quarantine of healthy individuals, and complete travel bans from high-risk areas were introduced by more than 130 countries. $[239,240]$ Certainly, travelers departing from Wuhan before the
Spring Festival were the main infection source for other cities in China.[241,242] The CDC advises avoiding all nonessential travel to all global destinations. Conversely, prolonged border closures goes against WHO's recommendation to avoid unnecessary restrictions on international traffic and trade.[240] Indeed, travel bans may interrupt deliveries of needed aid and technical support. [238] After careful risk assessment, restrictions must be revised regularly as the situation evolves to remain responsive in both measures and duration of the risk to public health.[243]

Travel restriction has often been debated. Understanding the implications of SARS-CoV-2 transmission is crucial for the formulation of containment strategies.[244] Airport screening was successful in identifying and blocking importation of up to $50 \%$ of dengue or Ebola cases presenting with fever in Taiwan. $[245,246]$ However, in the ongoing COVID-19 pandemic, airport screening effectiveness was estimated to be very limited given the disease's extended incubation period (beyond 14 days), which can result in low predictive values at screening locations.[247] Asymptomatic cases in their incubation period or cases concealing fever during travel could escape border controls and become infectious later to seed local transmission in destination countries.[30,248,249] Moreover, syndromic screening generates a high overhead of travelers who screen positive but are uninfected with the pathogen of interest. $[250,251]$ A reliable screening test (RT-PCR) can detect symptomatic and asymptomatic COVID-19 cases but will not provide instantaneous results.[252]

Statistical modeling estimated a $70.4 \%$ reduction in COVID-19 global incidence after travel bans, and a 7\%-20\% reduced probability of major epidemics in all countries. However, travel bans secured only a few days of delay in the spread of the epidemic which will not substantially help meaningful prevention.[253,254]

The risk of contracting the virus on regularly traveled public transportation in major cities may outweigh the risk of contracting the disease through international travel if physical distancing is not maintained. Accordingly, the contribution of global travel restrictions is relatively small unless paired with public health interventions (early detection, disease surveillance, social distancing, hand washing, sanitation, selfisolation, quarantine and case management) to maximize reduction of transmissibility.

Mass gatherings Large events and mass gatherings (MGs) such as concerts, festivals, conferences or sporting events have been sources of infectious disease spread and responsible for exacerbating the scope of pandemics.[255-257] However, the scale of the problem has declined over decades as better public health measures have been applied.[256,258,259] Behaviors in MGs like talking, sharing food or drinks and long periods of close sitting or standing can facilitate disease transmission. The role of MGs in SARS-CoV-2 transmission could be significant given the relatively high $R_{0}$.[260] In response to the COVID-19 pandemic and in line with social distancing guidance, government officials and responsible organizations in many countries have made decisions to cancel or postpone planned events.[261,263] Timing of restrictions should come closer to peaks in the epidemic and continue as 
long as the transmission fails to decrease.[260] Schools are closed and distance learning is being adopted. Venues where people congregate for nonessential purposes such as gyms, pools, movies, museums or recreation are closed. On the other hand, supermarkets, service stations, clinics, pharmacies, banking and other essential gathering services remain open. $[262,264]$ MG cancellation or suspension is critical to pandemic mitigation. [257,265] A large body of research in this area is based on modeling studies[257] and case reports, including the COVID-19 outbreaks on the Diamond Princess cruise ship[30] and carnivals in Latin America.[266]

Adherence to MG restrictions will aid emergency services and alleviate the burden on public health. Nevertheless, restrictions on MGs should be decided on the basis of context-specific risk assessment and clear rationale, bearing in mind their socioeconomic impacts and effects on the future wellbeing of communities. $[258,263]$

Refugees and migrants Given how quickly SARS-CoV-2 is spreading, it will inevitably establish a foothold in refugee and migrant communities and within internally-displaced settlements.[267] The risk is compounded by overcrowded living arrangements and the immense barriers to accessing healthcare services and sanitation facilities commonly found in these communities. Border closures and movement restrictions will likely increase as containment measures for COVID-19 control intensify, which will block refugee rights to seek asylum and humanitarian aid, particularly after the UN suspension of resettlement procedures.[267,268] The COVID-19 pandemic could devastate migrant populations without immediate action and enormous global support. For example, almost half the refugees in the Ellwangen refugee camp in Baden-Wurttemberg tested positive for SARS-CoV-2 (250 confirmed cases), and these individuals were forced to share facilities with everyone else. Moreover, about $80 \%$ of refugees live in low- and middleincome countries with compromised healthcare systems and reduced epidemic management capacity.[268] WHO calls on preparedness plans to consider refugees and address their needs in order to ensure no one will be left behind. Its proposed framework guides risk assessment, case management protocols, rapid deployment of outbreak response teams and linguistically accessible information about COVID-19.[269,270]

Homelessness Homeless people live in environments that are conducive to disease spread.[271] They live in congregate settings (tents, shelters or halfway houses, encampments, abandoned buildings, train or bus stations, tunnels) with shortage of basic needs and hygiene supplies. Moreover, homeless individuals engage in high rates of substance abuse, have poor health status, and experience 5-10 times higher all-cause mortality than the general population.[271,272] People experiencing homelessness are at a catastrophic risk of infection during the community spread of SARS-CoV-2. [273] More particularly, mentally-ill homeless individuals will not be able to cope with the situation in recognizing and responding to the threat of infection.[273] These circumstances challenge attempts to stem SARS-CoV-2 in countries with sizable unsheltered populations.[273,274] As cities impose a lockdown to prevent SARS-CoV-2 transmission, emergency preparedness plans to protect and accommodate people experiencing homelessness are few. In the USA, in response to the COVID-19 crisis, action is being taken to relocate many of homeless people to hotels. In fact, homelessness requires additional measures and resources. In the USA, the CDC has issued interim guidance to support response planning by emergency management and public health authorities in order to respond to the needs of homeless populations in the face of the epidemic.[275]

Drug addiction COVID-19 could hit populations with substance abuse disorders (SUDs) particularly hard.[276] Very little is known about SARS-CoV-2 and its intersection with SUDs. However, people who use drugs (PWUD) including opioids, methamphetamine or cannabis, might face an increased risk of COVID-19 and its more serious complications given their effects on cardiopulmonary health as well as on the immune system. [276] Compromised breathing is the main life-threatening effect of opioid abuse, which can be further aggravated by COVID-19 and manifest as an overdose.[276,277]

The current public health crisis raises additional serious concerns for PWUDs. Indeed, recreational drug use often takes place within congregate settings where smoking or injecting equipment potentially contaminated with SARSCoV-2 are shared.[278] Prospects of self-quarantine and other public health restrictions may also disrupt regular access to syringe exchange services, medications and other needed support. Moreover, PWUDs experience housing instability and limited access to health care at higher rates than the rest of the population. Fear of stigmatization will create an additional barrier to treatment for COVID-19.[276]

Smoking and tobacco use Mounting evidence has attributed differences in COVID-19 prevalence and severity to smoking. [279-281] Two meta-analyses of relevant epidemiological studies conducted in China supported the argument that smoking is most likely associated with the negative progression and adverse outcomes of COVID-19.[282,283] Conversely, reports from several studies questioned the role of coexisting active smoking as a risk factor for COVID-19 pneumonia,[284] and even suggest a protective role.[285] In this regard, epidemiological data showed that smokers were underrepresented among COVID-19 patients, with no significant association between current smoking and severe disease.[94,286-288]

Interestingly, the prevalence of current smoking among hospitalized COVID-19 cases in China, France and the USA was low (approximately one third the anticipated prevalence when considering smoking prevalence in the general population). French researchers suggested that the nicotinic acetylcholine receptor (nAChR) plays a key role in the pathophysiology of SARS-CoV-2 infection and thus presents a target for its prevention and control. This legitimizes controlled use of nicotine to compete with SARS-CoV-2 binding to the nAChR. A therapeutic assay of nicotine patches against COVID-19 is planned to test this theory at Pitié-Salpêtrière hospital in Paris.[289]

Controversial inferences from the latest epidemiological studies should be interpreted with caution, given the limited available data and unadjusted results for other factors that may 
affect disease outcomes. In fact, smokers are likely to be more vulnerable to contracting COVID-19, as the act of smoking involves frequent hand to mouth contact. Moreover, preexisting lung damage puts smokers at a higher risk of serious lung illness such as pneumonia.[290]

The CDC suggests that COVID-19 has a case fatality rate of $6.3 \%$ for individuals with chronic respiratory disease, compared with $2.3 \%$ overall.[291] In waterpipe smoking, a single mouthpiece and hose are often shared among users in communal and social settings. In addition, the waterpipe apparatus is not cleaned between sessions, thus promoting the survival of contaminating microorganisms. These factors provide ample opportunity for SARS-CoV-2 and other infectious diseases to spread between users.[292] Likewise, vaping may also harm lung health. Emerging evidence suggests that exposure to aerosols from e-cigarettes causes lung injury and diminishes the ability to respond to infection.[293]

Imprisonment Detention environments are breeding grounds for infectious diseases.[294,295] Infection rates in prisons are fueled by overcrowding, poor ventilation, unsanitary facilities, high risk behaviors, deficient healthcare services and the weighting of security over public health concerns.[294-296] Moreover, prisoners have restricted access to common hygiene products containing ingredients usually deemed contraband, such as alcohol-based hand sanitizer.[295]

Alarming clusters of COVID-19-related deaths have erupted among incarcerated persons and prison staff.[297] Over 10 million people are incarcerated worldwide,[298] which makes prisons a worldwide flashpoint for the disease's spread.[299] The incarcerated population is at heightened risk for contracting COVID-19 as well as for developing severe disease-related complications due to normative multimorbidity and accelerated aging.[297,300]

The response to COVID-19 in prisons and other places of detention is challenging and requires a holistic approach. Government officials from many countries adopted measures for limited prisoner release to reduce the incidence of in-custody transmission.[297] However, release without a plan poses the risk of viral spread to the local general population. In this regard, WHO has issued prison-specific guidance for responding to COVID-19. It suggests: i) joint planning to integrate prison health in the overall public health response, ii) risk management to limit transmission and spread within and beyond prisons, formulating adequate prevention and control protocols for entry screening, personal protection, social distancing, environmental cleaning and disinfection, restriction of movement and limited access for visitors, iii) treatment, specialized care and isolation of cases and contacts and iv) facilitation of timely information sharing and establishment of close collaboration between healthcare and justice sectors.[301]

\section{CONCLUDING REMARKS}

Ferreting out scientifically sound information among inadequate, misinformed and controversial reports is a hard task. In consequence, an in-depth analysis of published scientific information is mandatory.

SARS-CoV-2 transmission and infection research is as essential today as it was at the beginning of the pandemic. The transition to a post-pandemic phase poses new problems regarding transmission, with profound social consequences. Undoubtedly, the post-pandemic period will highlight aspects of transmission that we are unable to foresee today. Until there is a safe and effective vaccine, and certainly, afterwards, research on the routes of transmission of the virus will remain a top priority. $-1 /$.

\section{REFERENCES}

1. Singhal T. A review of Coronavirus disease-2019 (COVID-19). Indian J Pediatr. 2020 Apr;87(4):281-6.

2. World Health Organization [Internet]. Geneva: World Health Organization; c2020. Coronavirus disease (COVID-2019). Situation reports. Coronoavirus disease (COVID-19) Weekly Epidemiological Update and Weekly Operational Update; [cited 2020 Aug 2]. Available at: https://www .who.int/emergencies/diseases/novel-coronavi rus-2019/situation-reports

3. van Doremalen $\mathrm{N}$, Bushmaker $\mathrm{T}$, Morris $\mathrm{DH}$, Holbrook MG, Gamble A, Williamson BN, et al. Aerosol and surface stability of SARS-CoV-2 as compared with SARS-CoV-1. N Engl J Med. 2020 Apr 16;382(16):1564-7.

4. Lesho E, Laguio-Vila M, Walsh E. Stability and Viability of SARS-CoV-2. N Engl J Med. 2020 May 14;382(20):1963-4.

5. Rubens JH, Karakousis PC, Jain SK. Stability and Viability of SARS-CoV-2. N Engl J Med. 2020 May 14;382(20):1962-3.

6. Schwartz KL, Kim J, Garber G. Stability and Viability of SARS-CoV-2. N Engl J Med. 2020 May 14;382(20):1963.

7. Helmers A. Stability and Viability of SARS-CoV-2. N Engl J Med. 2020 May 14;382(20):1964.

8. Petti S. Stability and Viability of SARS-CoV-2. N Engl J Med. 2020 May 14;382(20):1964-5.

9. Kampf G, Todt D, Pfaender S, Steinmann E. Persistence of coronaviruses on inanimate surfaces and their inactivation with biocidal agents. J Hosp Infect. 2020 Mar;104(3):246-51.

10. Grass G, Rensing C, Solioz M. Metallic copper as an antimicrobial surface. Appl Environ Microbiol. 2011 Mar;77(5):1541-7

11. Pastorino B, Touret F, Gilles M, de Lamballerie X Charrel RN. Evaluation of heating and chemical protocols for inactivating SARS-CoV-2. bioRxiv [Internet]. Yale: BMJ Yale; 2020 Apr 11 [cited 2020 Apr 20]. Available at: https://www.biorxiv .org/content/10.1101/2020.04.11.036855v1

12. Chin A, Chu J, Perera M, Hui K, Yen H-L, Chan $M$, et al. Stability of SARS-CoV-2 in different environmental conditions. medRxiv [Internet]. New York: Cold Spring Harbor Lab; 2020 Mar 27 [cited 2020 Apr 20]. Available at: https://www.medrxiv .org/content/10.1101/2020.03.15.20036673v2 .article-info

13. National Health Commission of the People's Republic of China [Internet]. Beijing: National Health Commission of the People's Republic of China; c2020. News. No evidence to suggest coronavirus will disappear in summer: WHO expert; 2020 Mar 7 [cited 2020 Mar 7]. Available at: http://en.nhc.gov.cn/2020-03/07/c_77446.htm

14. Bukhari Q, Jameel Y. Will coronavirus pandemic diminish by summer?[Internet].New York: SSRN; 2020 Mar 19 [cited 2020 Apr 20]. Available at: https://dx.doi.org/10.2139/ssrn.3556998

15. Wang J, Tang K, Feng K, Lin X, Lv W, Chen K, et al. High temperature and high humidity reduce the transmission of COVID-19 [Internet]. New York: SSRN; 2020 Mar 10 [cited 2020 Apr 20]. 33 p. Available at: https://papers.ssrn.com/sol3/ papers.cfm?abstract id $=3551767$

16. Sajadi MM, Habibzadeh P, Vintzileos A, Shokouhi $\mathrm{S}$, Miralles-Wilhelm F, Amoroso A. Temperature, humidity and latitude analysis to predict potentia spread and seasonality for COVID-19 [Internet] New York: SSRN; 2020 Mar 9 [cited 2020 Apr $20] .18$ p. Available at: http://dx.doi.org/10.2139/ ssrn.3550308

17. Lipsitch M. Seasonality of SARS-CoV-2: Will COVID-19 go away on its own in warmer weather? [Internet]. Boston: Harvard T.H. Chan School of Public Health; 2020 [cited 2020 Jul 31]; [about 2 p.]. Available at: https://ccdd.hsph.harvard .edu/will-covid-19-go-away-on-its-own-in-warmer -weather/

18. Wu Y, Jing W, Liu J, Ma Q, Yuan J, Wang $Y$, et al. Effects of temperature and humidity on the daily new cases and new deaths of COVID-19 in 166 countries. Sci Total Environ. 2020 Aug 10;729:139051. DOI: 10.1016/j.scitotenv.2020.139051.

19. Mecenas P, Bastos R, Vallinoto A, Normando $D$. Effects of temperature and humidity on the spread of COVID-19: A systematic review. medRxiv [Internet].New York: Cold Spring Harbor Lab; 2020 Apr 17 [cited 2020 Jul 15]. 31 p. Available at: https://www.medrxiv.org/content/10.1101 /2020.04.14.20064923v1.full.pdf+html 
20. Kowalski W, Walsh T, Petraitis V. 2020 COVID-19 Coronavirus Ultraviolet Susceptibility. Techniqual report. PurpleSun Inc2020 [Internet]. Berlin: ResearchGate; 2020 Mar [cited 2020 Jul 15]; [about 3 p.]. Available at: https://www.researchgate.net/publi cation/339887436_2020_COVID-19_Coro navirus Ultraviolet Susceptibility

21. Bianco A, Biasin M, Pareschi G, Cavalleri A, Cavatorta C, Fenizia C, et al. UV-C irradiation is highly effective in inactivating and inhibiting SARS-CoV-2 replication. medRxiv [Internet]. New York: Cold Spring Harbor Lab; 2020 Jun 23 [cited 2020 Jul 15]. Available at: https://www.medrxiv .org/content/10.1101/2020.06.05.20123463v2

22. Health Europe [Internet]. Congleton (UK): Pan European Networks Ltd; c2018. Infection Control News. Breakthrough ultraviolet light development could help kill COVID-19 virus; 2020 Jun 2 [cited 2020 Aug 2]; [about 2 p.]. Available at: https:// www.healtheuropa.eu/breakthrough-ultraviolet -light-development-could-help-kill-covid-19-vi rus/100409/

23. Du Z, Xu X, Wu Y, Wang L, Cowling BJ, Meyers LA. Serial interval of COVID-19 among publicly reported confirmed cases. Emerg Infect Dis. 2020 Jun;26(6):1341-3.

24. Qian G, Yang N, Ma AHY, Wang L, Li G, Chen $X$, et al. COVID-19 Transmission within a family cluster by presymptomatic carriers in China. Clin Infect Dis. 2020 Jul 28;71(15):861-2.

25. Wei WE, Li Z, Chiew CJ, Yong SE, Toh MP, Lee VJ. Presymptomatic Transmission of SARSCoV-2-Singapore. MMWR Morb Mortal Wkly Rep. 2020 Apr 10;69(14):41-5.

26. Zhou F, Yu T, Du R, Fan G, Liu Y, Liu Z, et al. Clinical course and risk factors for mortality of adult in patients with COVID-19 in Wuhan, China: a retrospective cohort study. Lancet. 2020 Mar 28;395(10229):1054-62.

27. Liu WD, Chang SY, Wang JT, Tsai MJ, Hung CC Hsu $\mathrm{CL}$, et al. Prolonged virus shedding even after seroconversion in a patient with COVID-19. J Infect. Epub 2020 Apr 10.

28. Zhou B, She J, Wang Y, Ma X. The duration of viral shedding of discharged patients with severe COVID-19. Clin Infect Dis. 2020 Apr 17. pii: ciaa451. DOI: 10.1093/cid/ciaa451. [Epub ahead of print]

29. Li Q, Guan X, Wu P, Wang X, Zhou L, Tong Y, et al. Early transmission dynamics in Wuhan, China, of Novel Coronavirus-Infected Pneumonia. N Engl J Med. 2020 Mar 26;382(13):1199-207.

30. Dahl E. Coronavirus (Covid-19) outbreak on the cruise ship Diamond Princess. Int Marit Health. 2020;71(1):5-8

31. Kucharski AJ, Russell TW, Diamond C, Liu Y, Edmunds J, Funk S, et al. Early dynamics of transmission and control of COVID-19: a mathematical modelling study. Lancet Infect Dis. 2020 May;20(5):553-8. Epub 2020 Mar 11.

32. Liu Y, Gayle AA, Wilder-Smith A, Rocklöv J. The reproductive number of COVID-19 is higher compared to SARS coronavirus. J Travel Med. 2020 Mar 13;27(2).

33. Sanche $\mathrm{S}$, Lin $\mathrm{YT}, \mathrm{Xu} \mathrm{C}$, Romero-Severson $\mathrm{E}$ Hengartner N, Ke R. High Contagiousness and rapid spread of Severe Acute Respiratory Syndrome Coronavirus 2. Emerg Infect Dis. 2020 Jul 7;26(7):1470-7.

34. Yuan J, Li M, Lv G, Lu ZK. Monitoring transmissibility and mortality of COVID-19 in Europe. Int J Infect Dis. 2020 Jun 95:311-5. Epub 2020 Mar 28

35. Cole EC, Cook CE. Characterization of infectious aerosols in health care facilities: an aid to effective engineering controls and preventive strategies. Am J Infect Control. 1998 Aug;26(4):453-64.

36. Duguid JP. The size and the duration of aircarriage of respiratory droplets and droplet- nuclei. J Hyg (Lond). 1946 Sep;44(6):471-9

37. Hamburger M Jr, Robertson OH. Expulsion of group A hemolytic streptococci in droplets and droplet nuclei by sneezing, coughing and talking Am J Med. 1948 May;4(5):690-701.

38. Loudon RG, Roberts RM. Relation between the airborne diameters of respiratory droplets and the diameter of the stains left after recovery. Nature. 1967 Jan 7;213(5071):95-6.

39. Yang $\mathrm{C}, \mathrm{Ma}$ QY, Zheng $\mathrm{YH}$, Yang YX. [Transmission routes of 2019-novel coronavirus (2019nCoV)]. Zhonghua Yu Fang Yi Xue Za Zhi. 2020 Apr 6;54(4):374-7. Chinese.

40. Fennelly KP. Particle sizes of infectious aerosols: implications for infection control. Lancet Respir Med. 2020 July 24;8(9):914-24.

41. Somsen GA, van Rijn C, Kooij S, Bem RA, Bonn D. Small droplet aerosols in poorly ventilated spaces and SARS-CoV-2 transmission. Lance Respir Med. 2020 Jul;8(7):658-9.

42. Lewis D. Is the coronavirus airborne? Experts can't agree. Nature. 2020 Apr;580(7802):175.

43. Medical Xpress [Internet]. Douglas (UK): Science X; c2011-2020. Diseases, Conditions, Syndroms. How Important Is Speech in Transmitting Coronavirus?; 2020 Apr 3 [cited 2020 May10] [about 2 p.]. Available at: https://medicalxpress .com/news/2020-04-important-speech-transmit ting-coronavirus.html

44. Rapid Expert Consultation on the Possibility of Bioaerosol Spread of SARS-CoV-2 for the COVID-19 Pandemic [Internet]. Washington, D.C.: National Academies of Sciences, Engineering, and Medicine; 2020 Apr 1 [cited 2020 May 10]. 3 p. Available at: https://www.nap.edu/ catalog/25769/rapid-expert-consultation-on-the -possibility-of-bioaerosol-spread-of-sars-cov-2 -for-the-covid-19-pandemic-april-1-2020

45. Bourouiba L. Turbulent gas clouds and respiratory pathogen emissions: potential implications for reducing transmission of COVID-19. JAMA. 2020 Mar 26. DOI: 10.1001/jama.2020.4756

46. Guo ZD, Wang ZY, Zhang SF, Li X, Li L, Li C, et al. Aerosol and surface distribution of severe acute respiratory syndrome coronavirus 2 in hospital wards, Wuhan, China, 2020. Emerg Infect Dis. 2020 Jul;26(7):1583-91.

47. Santarpia JL, Rivera DN, Herrera V, Morwitzer MJ, Creager H, Santarpia GW, et al. Transmission potential of SARS-CoV-2 in viral shedding observed at the University of Nebraska Medical Center. medRxiv [Internet]. New York: Cold Spring Harbor Lab; 2020 Jun 3 [cited 2020 Jun 10]. 12 p. Available at: https://www.medrxiv.org/ content/10.1101/2020.03.23.20039446v2.full.pdf

48. Liu Y, Ning Z, Chen Y, Guo M, Liu Y, Gali NK, et al. Aerodynamic characteristics and RNA concentration of SARS-CoV-2 aerosol in Wuhan hospitals during COVID-19 outbreak. bioRxiv [Internet]. New York: Cold Spring Harbor Lab 2020 Mar 10 [cited 2020 Mar 22]. Available at: https://www.biorxiv.org/content/10.1101/2020.03 $.08 .982637 \mathrm{~V} 1$

49. Cheng VCC, Wong S-C, Chen JHK, Yip CCY, Chuang VWM, Tsang OTY, et al. Escalating infection control response to the rapidly evolving epidemiology of the coronavirus disease 2019 (COVID-19) due to SARS-CoV-2 in Hong Kong. Infect Control Hosp Epidemiol. 2020 May:41(5):493-8.

50. Ong SWX, Tan YK, Chia PY, Lee TH, Ng OT Wong MSY, et al. Air, surface environmental, and personal protective equipment contamination by Severe Acute Respiratory Syndrome Coronavirus 2 (SARS-CoV-2) from a symptomatic patient. JAMA. 2020 Mar 4. DOI: 10.1001/ jama.2020.3227.

51. Faridi S, Niazi S, Sadeghi K, Naddafi K, Yavarian J, Shamsipour M, et al. A field indoor air mea- surement of SARS-CoV-2 in the patient rooms of the largest hospital in Iran. Sci Total Environ. 2020 Jul 10;725:138401. Epub 2020 Apr 6

52. World Health Organization [Internet]. Geneva: World Health Organization; c2020. Newsroom. Modes of transmission of virus causing COVID-19: implications for IPC precaution recommendations; 2020 Mar 29 [cited 2020 Apr 26]; [about 5 p.]. Available at: https://www.who int/news-room/commentaries/detail/modes-of -transmission-of-virus-causing-covid-19-implica tions-for-ipc-precaution-recommendations

53. To KK, Tsang OT, Chik-Yan Yip C, Chan $\mathrm{KH}$, Wu TC, Chan JMC, et al. Consistent detection of 2019 novel coronavirus in saliva. Clin Infect Dis [Internet]. 2020 Jul 28 [cited 2020];71(15):841-3. Available at: https://www.ncbi.nlm.nih.gov/pmc/articles/ pmid/32047895/

54. New insights into the transmissibility of the virus. Berlin: BioValley; 2020.

55. Setti L, Passarini F, De Gennaro G, Barbieri P, Perrone MG, Borelli M, et al. Airborne transmission route of COVID-19: why 2 meters/ 6 feet of inter-personal distance could not be enough. Int J Environ Res Public Health. 2020 Apr 23;17(8).

56. Zhang R, Li Y, Zhang AL, Wang Y, Molina MJ. Identifying airborne transmission as the dominant route for the spread of COVID-19. Proc Natl Acad Sci U S A. 2020 Jun 30;117(26):14857-63.

57. Setti L, Passarini F, De Gennaro G, Barbieri P, Perrone MG, Piazzalunga $A$, et al. The potential role of particulate matter in the spreading of COVID-19 in Northern Italy: first evidencebased research hypotheses. medRxiv [Internet]. New York: Cold Spring Harbor Lab;2020 Apr 17 [cited 2020 May 20]. Available at: https://www.medrxiv.org/content/10.1101/2020.0 4.11.20061713v1

58. World Health Organization [Internet]. Geneva: World Health Organization; c2020. Newsroom. Transmission of SARS-CoV-2: implications for infection prevention precautions; 2020 Jul 9 [cited 2020 Jul 31]; [about 10 p.]. Available at: https://www who.int/news-room/commentaries/ detail/transmission-of-sars-cov-2-implications -for-infection-prevention-precautions

59. Pancic F, Carpentier DC, Came PE. Role of infectious secretions in the transmission of rhinovirus. J Clin Microbiol. 1980 Oct:12(4):567-71.

60. Special Expert Group for Control of the Epidemic of Novel Coronavirus Pneumonia of the Chinese Preventive Medicine Association. [An update on the epidemiological characteristics of novel coronavirus pneumonia COVID-19]. Zhonghua Liu Xing Bing Xue Za Zhi. 2020 Feb 10;41(2):13944. Chinese.

61. Hamzelou J. Should you disinfect your online shopping? New Sci. 2020 Apr 4;245(3276):12.

62. New Group of Experts on the prevention and control of Chinese Preventive Medicine Association coronavirus pneumonia. The latest understanding of the epidemiological characteristics of pneumonia novel coronavirus. Chinese J Epidemiol. 2020.

63. Hamming I, Timens $\mathrm{W}$, Bulthuis ML, Lely AT, Navis G, van Goor H. Tissue distribution of ACE2 protein, the functional receptor for SARS coronavirus. A first step in understanding SARS pathogenesis. J Pathol. 2004 Jun;203(2):631-7.

64. Xu H, Zhong L, Deng J, Peng J, Dan H, Zeng X et al. High expression of ACE2 receptor of 2019nCoV on the epithelial cells of oral mucosa. Int $\mathrm{J}$ Oral Sci. 2020 Feb 24;12(1):8.

65. Zhang $\mathrm{H}$, Kang Z, Gong H, Xu D, Wang J, Li Z, et al. The digestive system is a potential route of 2019-nCov infection: a bioinformatics analysis based on single-cell transcriptomes. bioRxiv [Internet]. New York: Cold Spring Harbor Lab; 
2020 Jan 31 [cited 2020 Feb 19]. Available at: https://www.biorxiv.org/content/10.1101/2020.01 30.927806v1

66. Sahu KK, Mishra AK, Lal A. COVID-2019: update on epidemiology, disease spread and management. Monaldi Arch Chest Dis. 2020 Apr 16;90(1).

67. Xiao F, Tang M, Zheng X, Liu Y, Li X, Shan $H$. Evidence for gastrointestinal infection of SARS-CoV-2. Gastroenterology. 2020 May;158 (6):1831-3

68. Kotfis K, Skonieczna-Zydecka K. COVID-19: gastrointestinal symptoms and potential sources of 2019-nCoV transmission. Anaesthesiol Intensive Ther. 2020;52(2):172-3

69. Gu J, Han B, Wang J. COVID-19: Gastrointestinal manifestations and potential fecaloral transmission. Gastroenterology. 2020 May;158(6):1518-9.

70. World Health Organization. Report of the WHOChina Joint Mission on Coronavirus Disease 2019 (COVID-19) [Internet]. Geneva: World Health Organization; 2020 Feb 16-24 [cited 2020 Apr 27]. Available at: https://www.who. int/docs/defaultsource/coronaviruse/who-china -joint-mission-on-covid-19-final-report.pdf

71. Yong Z, Cao C, Shuangli Z, Chang S, Dongyan W, Jingdong S, et al. Isolation of 2019-nCoV from a Stool Specimen of a Laboratory-Confirmed Case of the Coronavirus Disease 2019 (COVID-19). China CDC Weekly. 2020;2(8):123-4.

72. Pan $Y$, Zhang D, Yang $P$, Poon LLM, Wang Q. Viral load of SARS-CoV-2 in clinical samples. Lancet Infect Dis. 2020 Apr;20(4):411-2.

73. Zheng S, Fan J, Yu F, Feng B, Lou B, Zou Q, et al. Viral load dynamics and disease severity in patients infected with SARS-CoV-2 in Zhejiang province, China, January-March 2020: retrospective cohort study. BMJ. 2020 Apr 21;369:m1443.

74. Cheung KS, Hung IFN, Chan PPY, Lung KC, Tso E, Liu R, et al. Gastrointestinal manifestations of SARS-CoV-2 infection and virus load in fecal samples from the Hong Kong cohort and systematic review and meta-analysis. Gastroenterology. 2020 Jul;159(1):81-95.

75. Bulut C, Kato Y. Epidemiology of COVID-19. Turk J Med Sci. 2020 Apr 21:50(SI-1):563-70.

76. Chen W, Lan Y, Yuan X, Deng X, Li Y, Cai X, et al. Detectable 2019-nCoV viral RNA in blood is a strong indicator for the further clinical severity. Emerg Microbes Infect. 2020 Feb 26;9(1):469-73.

77. Holshue ML, DeBolt C, Lindquist S, Lofy $\mathrm{KH}$, Wiesman J, Bruce $\mathrm{H}$, et al. First case of 2019 novel coronavirus in the United States. New Engl J Med. 2020 Mar 5;382(10):929-30.

78. Zhang J, Wang S, Xue Y. Fecal specimen diagnosis 2019 novel coronavirus-infected pneumonia. J Med Virol. 2020 Jun;92(6):680-2.

79. Yeo C, Kaushal S, Yeo D. Enteric involvement of coronaviruses: is faecal-oral transmission of SARS-CoV-2 possible? Lancet Gastroenterol Hepatol. 2020 Apr;5(4):335-7.

80. Nouri-Vaskeh M, Alizadeh L. Fecal transmission in COVID-19: a potential shedding route. J Med Virol. 2020 Apr 1. DOI: 10.1002/jmv.25816. [Epub ahead of print]

81. Chen $Y$, Chen L, Deng $Q$, Zhang G, Wu K, Ni $\mathrm{L}$, et al. The presence of SARS-CoV-2 RNA in the feces of COVID-19 patients. J Med Virol. 2020 Jul;92(7):833-40.

82. Wu Y, Guo C, Tang L, Hong Z, Zhou J, Dong X, et al. Prolonged presence of SARS-CoV-2 viral RNA in faecal samples. Lancet Gastroenterol Hepatol. 2020 May;5(5):434-5

83. Xiao F, Sun J, Xu Y, Li F, Huang X, Li H, et al Infectious SARS-CoV-2 in feces of patient with severe COVID-19. Emerg Infect Dis. 2020 Aug;26(8):1920-2.

84. Wang W, Xu Y, Gao R, Lu R, Han K, Wu G, et al. Detection of SARS-CoV-2 in different types of clinical specimens. JAMA. 2020 Mar 11. DOI: 10.1001/jama.2020.3786. [Epub ahead of print]

85. Chan WM, Yuen KS, Fan DS, Lam DS, Chan PK, Sung JJ. Tears and conjunctival scrapings for coronavirus in patients with SARS. Br J Ophthalmol. 2004 Jul;88(7):968-9.

86. Lu CW, Liu XF, Jia ZF. 2019 nCoV transmission through the ocular surface must not be ignored. Lancet. 2020 Feb 22;395(10224):e39.

87. Seah I, Agrawal R. Can the Coronavirus disease 2019 (COVID-19) affect the eyes? A review of Coronaviruses and ocular implications in humans and animals. Ocul Immunol Inflamm. 2020 Apr 2;28(3):391-5.

88. Colavita F, Lapa D, Carletti F, Lalle E, Bordi L, Marsella $P$, et al. SARS-CoV-2 isolation from ocular secretions of a patient with COVID-19 in Italy with prolonged viral RNA detection. Ann Intern Med. 2020 Aug 4;173(3):242-3.

89. Chen L, Liu M, Zhang Z, Qiao K, Huang T, Chen $M$, et al. Ocular manifestations of a hospitalised patient with confirmed 2019 novel coronavirus disease. Br J Ophthalmol. 2020 Jun;104(6):748-51.

90. Cheema M, Aghazadeh $H$, Nazarali S, Ting A, Hodges J, McFarlane A, et al. Keratoconjunctivitis as the initial medical presentation of the novel coronavirus disease 2019 (COVID-19): a case report. Can J Ophthalmol. 2020 Aug;55(4):e125-9.

91. Hong N, Yu W, Xia J, Shen Y, Yap M, Han W. Are ocular symptoms common in patients with COVID-19? [Internet]. New York: SSRN; 2020 Apr 1 [cited 2020 May 27]. 38 p. Available at: https:// papers.ssrn.com/sol3/papers.cfm?abstract id $=3559539$

92. Liang $\mathrm{L}, \mathrm{Wu} \mathrm{P}$. There may be virus in conjunctival secretion of patients with COVID-19. Acta Ophthalmol. 2020 May;98(3):223. DOI: 10.1111/ aos.14413.

93. Wu P, Duan F, Luo C, Liu Q, Qu X, Liang L, et al. Characteristics of ocular findings of patients with Coronavirus disease 2019 (COVID-19) in Hubei Province, China. JAMA Ophthalmol. 2020 Mar 31. DOI: 10.1001/jamaophthalmol.2020.1291 [Epub ahead of print]

94. Guan WJ, Ni ZY, Hu Y, Liang WH, Ou CQ, He JX, et al. Clinical characteristics of Coronavirus disease 2019 in China. N Engl J Med. 2020 Apr 30;382(18)1708-20.

95. Peng $\mathrm{Y}$, Zhou $\mathrm{YH}$. Is novel coronavirus disease (COVID-19) transmitted through conjunctiva? J Med Virol. 2020 Mar 16. DOI: 10.1002/ jmv.25753. [Epub ahead of print]

96. Kuo IC. A Rashomon moment? Ocular involvement and COVID-19. Ophthalmology. 2020 Jul;127(7):984-5.

97. Xia J, Tong J, Liu M, Shen Y, Guo D. Evaluation of coronavirus in tears and conjunctival secretions of patients with SARS-CoV-2 infection. J Medical Virol. 2020 Jun;92(6):589-94.

98. Jun ISY, Anderson DE, Kang AEZ, Wang L-F Rao $P$, Young BE, et al. Assessing viral shedding and infectivity of tears in coronavirus disease 2019 (COVID-19) patients. Ophthalmology. 2020 Jul;127(7):977-9

99. Jones L, Walsh K, Willcox M, Morgan P, Nichols J. The COVID-19 pandemic: Important considerations for contact lens practitioners. Cont Lens Anterior Eye. 2020 Jun;43(3):196-203.

100. Dong L, Tian J, He S, Zhu C, Wang J, Liu C, et al. Possible vertical transmission of SARS-CoV-2 from an infected mother to her newborn. JAMA. 2020 Mar 26.DOI: 10.1001/jama.2020.4621. [Epub ahead of print]

101. Zeng L, Xia S, Yuan W, Yan K, Xiao F, Shao J, et al. Neonatal early-onset infection with SARS-CoV-2 in 33 neonates born to mothers with COVID-19 in Wuhan, China. JAMA Pediatr. 2020 Mar 26. DOI: 10.1001/jamapediatrics.2020.0878. [Epub ahead of print]

102. Zeng $\mathrm{H}, \mathrm{Xu} \mathrm{C}$, Fan J, Tang $\mathrm{Y}$, Deng Q, Zhang $W$, et al. Antibodies in infants born to mothers with COVID-19 pneumonia. JAMA. 2020 Mar 26. DOI: 10.1001/jama.2020.4861.

103. Alzamora MC, Paredes T, Caceres D, Webb CM, Valdez LM, La Rosa M. Severe COVID-19 during pregnancy and possible vertical transmission. Am J Perinatol. 2020 Jun;37(8):861-5.

104. Kimberlin DW, Stagno S. Can SARS-CoV-2 infection be acquired in utero?: more definitive evidence is needed. JAMA. 2020 Mar 26. DOI: 10.1001/jama.2020.4868.

105. Ashraf MA, Keshavarz $P$, Hosseinpour $P$, Erfani A, Roshanshad A, Pourdast A, et al. Coronavirus Disease 2019 (COVID-19): asystematic review of pregnancy and the possibility of vertical transmission. J Reprod Infertil. 2020 JulSep;21(3):157-68.

106. Zhu H, Wang L, Fang C, Peng S, Zhang L, Chang G, et al. Clinical analysis of 10 neonates born to mothers with 2019-nCoV pneumonia. Transl Pediatr. 2020 Feb;9(1):51-60.

107. Li Y, Zhao R, Zheng S, Chen X, Wang J, Sheng $X$, et al. Lack of vertical transmission of Severe Acute Respiratory Syndrome Coronavirus 2, China. Emerg Infect Dis. 2020 Jun;26(6):1335-6.

108. Chen H, Guo J, Wang C, Luo F, Yu X, Zhang $W$, et al. Clinical characteristics and intrauterine vertical transmission potential of COVID-19 infection in nine pregnant women: a retrospective review of medical records. Lancet. 2020 Mar 7;395(10226):809-15.

109. Schwartz DA. An Analysis of 38 Pregnant women with COVID-19, their newborn infants, and maternal fetal transmission of SARS-CoV-2: maternal Coronavirus infections and pregnancy outcomes. Arch Pathol Lab Med. 2020 Mar 17.DOI: 10.5858/ arpa.2020-0901-SA. [Epub ahead of print]

110. Zhang L, Jiang $Y$, Wei $M$, Cheng BH, Zhou XC, Li $\mathrm{J}$, et al. [Analysis of the pregnancy outcomes in pregnant women with COVID-19 in Hubei Province]. Zhonghua Fu Chan Ke Za Zhi. 2020 Mar 25;55(3):166-71. Chinese.

111. Rasmussen SA, Smulian JC, Lednicky JA, Wen TS, Jamieson DJ. Coronavirus Disease 2019 (COVID-19) and pregnancy: what obstetricians need to know. Am J Obstet Gynecol. 2020 May;222(5):415-26.

112. Karimi-Zarchi $M$, Neamatzadeh $H$, Dastgheib SA, Abbasi H, Mirjalili SR, Behforouz A, et al. Vertical transmission of Coronavirus disease 19 (COVID-19) from infected pregnant mothers to neonates: a review. Fetal Pediatr Pathol. 2020 Jun;39(3):246-50.

113. Yang $\mathrm{H}$, Wang $\mathrm{C}$, Poon LC. Novel coronavirus infection and pregnancy. Ultrasound Obstetrics Gynecol. 2020 Apr;55(4):435-7.

114. Bouthry E, Picone O, Hamdi G, Grangeot-Keros L, Ayoubi JM, Vauloup-Fellous C. Rubella and pregnancy: diagnosis, management and outcomes. Prenat Diagn. 2014 Dec;34(13):1246-53.

115. Schmid MB, Fontijn J, Ochsenbein-Kölble N Berger C, Bassler D. COVID-19 in pregnant women. Lancet Infect Dis. 2020 Jun;20(6):653. DOI: 10.1016/S1473-3099(20)30175-4.

116. Ferrazzi E, Frigerio $L$, Savasi $V$, Vergani $P$, Prefumo $F$, Barresi $S$, et al. Vaginal delivery in SARS-CoV-2 infected pregnant women in Northern Italy: a retrospective analysis. BJOG. 2020 Apr 27. DOI: 10.1111/1471-0528.16278. [Epub ahead of print]

117. Iqbal SN, Overcash $R$, Mokhtari $N$, Saeed $H$, Gold S, Auguste T, et al. An uncomplicated delivery in a patient with Covid-19 in the United States. N Engl J Med. 2020 Apr 16;382(16):e34. 
118. Xiong X, Wei H, Zhang Z, Chang J, Ma X, Gao X, et al. Vaginal delivery report of a healthy neonate born to a convalescent mother with COVID19. J Med Virol. 2020 Apr 10. DOI: 10.1002/jmv.25857.

119. Grob R, Conzelmann C, Müller JA, Stenge S, Steinhart K, Kirchhoff F, et al. Detection of SARS-CoV-2 in human breastmilk. Lancet. 2020 Jun 6;395(10239):1757-8

120. World Health Organization [Internet]. Geneva: World Health Organization; c2020. Newsroom. Breastfeeding and COVID-19; 2020 Jun 23 [cited 2020 July 31]; [about 3 p.]. Available at: https://www.who.int/news-room/commentaries/ detail/breastfeeding-and-covid-19

121. Centers for Disease Control and Prevention (CDC) [Internet]. Atlanta: Centers for Disease Control and Prevention (CDC); c2020. Breastfeeding. Coronavirus disease (COVID-19) and breastfeeding; 2020 [cited 2020 Apr 28]. Available at: https://www.cdc.gov/breastfeeding/breastfeed ing-special-circumstances/maternal-or-infant -illnesses/covid-19-and-breastfeeding.html

122. Hussein J. COVID-19: What implications for sexual and reproductive health and rights globally? Sex Reprod Health Matters. 2020 Dec;28(1):1746065. DOI: 10.1080/ 26410397.2020.1746065.

123. Pan F, Xiao X, Guo J, Song Y, Li H, Patel DP, et al. No evidence of severe acute respiratory syndrome-coronavirus 2 in semen of males recovering from coronavirus disease 2019. Fertil Steril. 2020 Jun;113(6):1135-9.

124. Song C, Wang Y, Li W, Hu B, Chen G, Xia P, et al. Detection of 2019 novel coronavirus in semen and testicular biopsy specimen of COVID-19 patients. medRxiv [Internet]. New York: Cold Spring Harbor Lab; 2020 Apr 10 [cited 2020 May 20]. Available at: https://www.medrxiv.org/content/10 1101/2020.03.31.20042333v2.full.pdf

125. Cui P, Chen Z, Wang T, Dai J, Zhang J, Ding $\mathrm{T}$, et al. Clinical features and sexual transmission potential of SARS-CoV-2 infected female patients: a descriptive study in Wuhan, China. medRxiv [Internet]. New York: Cold Spring Harbor Lab; 2020 Feb 27 [cited 2020 Mar 15]. Available at: https://www.medrxiv.org/content/10.1101 /2020.02.26.20028225v1.full.pdf

126. Li D, Jin M, Bao P, Zhao W, Zhang S. Clinica characteristics and results of semen tests among men with coronavirus disease 2019. JAMA Netw Open. 2020 May 1;3(5):e208292.

127. Patri A, Gallo L, Guarino M, Fabbrocini G Sexual transmission of severe acute respiratory syndrome coronavirus 2 (SARS-CoV-2): a new possible route of infection? J Am Acad Dermatol. 2020 Jun;82(6):e227. DOI: 10.1016/j. jaad.2020.03.098.

128. Wang Z, Xu X. scRNA-seq profiling of human testes reveals the presence of the ACE2 receptor, a target for SARS-CoV-2 infection in Spermatogonia, Leydig and Sertoli cells. Cells. 2020 Apr 9;9(4):pii: E920.

129. Murdoch DR, French NP. COVID-19: another infectious disease emerging at the animal-human interface. N Z Med J. 2020 Feb 21;133(1510):12-5

130. Salata C, Calistri A, Parolin C, Palù G. Coronaviruses: a paradigm of new emerging zoonotic diseases. Pathog Dis. 2019 Dec 12;77(9). pii: ftaa006.DOI: 10.1093/femspd/ftaa006.

131. Lee PI, Hsueh PR. Emerging threats from zoonotic coronaviruses-from SARS and MERS to 2019-nCoV. J Microbiol Immunol Infect. 2020 Jun;53(3):365-7.

132. Ji W, Wang W, Zhao X, Zai J, Li X. Cross-species transmission of the newly identified Coronavirus 2019-nCoV. J Med Virol. 2020 Apr;92(4):433-40.

133. Zhou $P$, Yang $X L$, Wang $X G$, Hu B, Zhang $L$, Zhang $W$, et al. A pneumonia outbreak associat- ed with a new coronavirus of probable bat origin Nature. 2020 Mar;579(7798):270-3.

134. Paraskevis D, Kostaki EG, Magiorkinis G Panayiotakopoulos G, Sourvinos G,Tsiodras S Full-genome evolutionary analysis of the novel corona virus (2019-nCoV) rejects the hypothesis of emergence as a result of a recent recombination event. Infect Genet Evol. 2020 Apr;79:104212. DOI: 10.1016/j.meegid.2020.104212.

135. Callaway E, Cyranoski D. Why snakes probably aren't spreading the new China virus. London: Springer Nature; 2020 Jan 23 [cited 2020 Apr 25]. Available at: https://www.nature.com/ articles/d41586-020-001808?fbclid=IwAR2Wh sY7rHjl86vgRpyiaUYQkvvKR9mjYrbI3LXBL8xo qJVhnGmr5d4MZiY

136. Gorbalenya AE, Baker SC, Baric RS, de Groot RJ, Drosten C, Gulyaeva AA, et al. Severe acute respiratory syndrome-related coronavirus-The species and its viruses, a statement of the Coronavirus Study Group. bioRxiv [Internet]. NewYork: Cold Spring Harbor Lab; 2020 Feb 11 [cited 2020 Mar 19]. Available at: https://www.biorxiv .org/content/10.1101/2020.02.07.937862v1

137. Lu R, Zhao X, Li J, Niu P, Yang B, Wu H, et al. Genomic characterisation and epidemiology of 2019 novel coronavirus: implications for virus origins and receptor binding. Lancet. $2020 \mathrm{Feb}$ 22;395(10224):565-74.

138. Zhu N, Zhang D, Wang W, Li X, Yang B, Song $\mathrm{J}$, et al. A novel Coronavirus from patients with pneumonia in China, 2019. N Engl J Med. 2020 Feb 20;382(8):727-33.

139. Ren LL, Wang YM, Wu ZQ, Xiang ZC, Guo L, $\mathrm{Xu} T$, et al. Identification of a novel Coronavirus causing severe pneumonia in human: a descriptive study. Chinese Med J (Engl). 2020 May 5;133(9):1015-24

140. Benvenuto D, Giovanetti M, Ciccozzi A, Spoto S, Angeletti S, Ciccozzi M. The 2019-new coronavirus epidemic: evidence for virus evolution. J Medi Virol. 2020 Apr;92(4):455-9.

141. Wan Y, Shang J, Graham R, Baric RS, Li F. Receptor Recognition by the novel Coronavirus from Wuhan: an analysis based on decade-long structural studies of SARS Coronavirus. J Virol. 2020 Mar 17;94(7). pii: e00127-20. DOI: 10.1128/JVI.00127-20.

142. Andersen KG, Rambaut A, Lipkin WI, Holmes EC, Garry RF. The proximal origin of SARS-CoV-2. Nat Med. 2020 Apr;26(4):450-2.

143. Calisher C, Carroll D, Colwell R, Corley RB Daszak P, Drosten C, et al. Statement in support of the scientists, public health professionals, and medical professionals of China combatting COVID-19. Lancet. 2020 Ma 7;395(10226):e42-e3.

144. Biscayart C, Angeleri P, Lloveras S, Chaves TDSS, Schlagenhauf P, Rodríguez-Morales AJ. The next big threat to global health? 2019 nove coronavirus (2019-nCoV): what advice can we give to travellers?-Interim recommendations January 2020, from the Latin-American Society for Travel Medicine (SLAMVI). Travel Med Infect Dis. 2020;33:101567.

145. Rodríguez-Morales AJ, Bonilla-Aldana DK, BalbinRamon GJ, Rabaan AA, Sah R, Paniz-Mondolfi A et al. History is repeating itself: Probable zoonotic spillover as the cause of the 2019 novel Coronavirus epidemic. Infez Med. 2020 Mar 1;28(1):3-5

146. Ahmad T, Khan M, Haroon, Musa TH, Nasir S, Hui J, et al. COVID-19: zoonotic aspects. Travel Med Infect Dis. 2020 Feb 27:101607.

147. Li HY, Zhu GJ, Zhang YZ, Zhang LB, Hagan EA Martinez $S$, et al. A qualitative study of zoonotic risk factors among rural communities in southern China. Int Health. 2020 Feb 12;12(2):77-85.

148. Almendros A. Can companion animals become infected with Covid-19? Vet Rec. 2020 Mar 28;186(12):388-9.
149. Parry NMA. COVID-19 and pets: when pandemic meets panic. Forensic Sci Int: Reports. 2020 Dec;2:100090.

150. Sit THC, Brackman CJ, Ip SM, Tam KWS, LawPYT, To EMW, et al. Infection of dogs with SARS-CoV-2 [Internet]. London: Springer Nature; 2020 May 14 [cited 2020 Jun 16]; [about 6 p.]. Available at: https://www.nature.com/articles/s41586-020-23 34-5

151. Li X. Can cats become infected with Covid-19? Vet Rec. 2020 Apr 18;186(14):457-8

152. Newman A, Smith D, Ghai RR, Wallace RM, Torchetti MK, Loiacono C, et al. First reported cases of SARS-CoV-2 infection in companion animals - New York, MarchApril 2020. MMWR Morb Mortal Wkly Rep. 2020 Jun 12:69(23):710-3.

153. Oreshkova N, Molenaar R-J, Vreman S, Harders F, Munnink BBO, Hakze R, et al. SARS-CoV2 infection in farmed mink, Netherlands, April 2020. bioRxiv [Internet]. New York: Cold Spring Harbor Lab; 2020 May 18 [cited 2020 May 27]. Available at: https://www.biorxiv.org/content/10.1101/2020 05.18.101493v1

154. Centers for Disease Control and Prevention (CDC) [Internet]. Atlanta: Centers for Disease Control and Prevention (CDC); Coronavirus disease (COVID-19). Your Health. COVID-19 and Animals; [updated 2020 Aug 24; cited 2020 Apr 28]. Available at: https://www.cdc.gov/coronavirus/2019 -ncov/daily-life-coping/animals.html

155. Shanthikumar SR. We should err on side of caution with Covid-19 advice. Vet Rec. 2020 Apr 18;186(14):458. DOI: 10.1136/vr.m1488.

156. Lu J, Gu J, Li K, Xu C, Su W, Lai Z, et al. Early release-COVID-19 outbreak associated with air conditioning in restaurant, Guangzhou, China, 2020. Emerg Infect Dis. 2020 Jul;26:1320-3.

157. Dietz L, Horve PF, Coil DA, Fretz M, Eisen JA, Van Den Wymelenberg K. 2019 novel Coronavirus (COVID-19) pandemic: built environment considerations to reduce transmission. mSystems. 2020 Apr 7;5(2).pii: e00245-20. DOI: 10.1128/mSystems.00245-20.

158. Centers for Disease Control and Prevention (CDC) [Internet]. Atlanta: Center for Disease Control and Prevention (CDC); c2020. Coronavirus Disease 2019 (COVID-19). Health Departments. COVID-19 and Cooling Centers; [updated 2020 Apr 11; cited 2020 Apr 28]. Available at: https://www.cdc.gov/coronavirus/2019 -ncov/php/cooling-center.html

159. Zhang J, Tian S, Lou J, Chen Y. Familial cluster of COVID-19 infection from an asymptomatic. Crit Care. 2020 Mar 27;24(1):119. DOI: 10.1186/ s13054-020-2817-7.

160. Jing QL, Liu MJ, Yuan J, Zhang ZB, Zhang AR, Dean NE, et al. Household secondary attack rate of COVID-19 and associated determinants. medRxiv [Internet]. New York: Cold Spring Harbor Lab; 2020 Apr 15 [cited 2020 Apr 25]. Available at: https://www.medrxiv.org/content/10.1101 /2020.04.11.20056010v1

161. Hu Z, Song C, Xu C, Jin G, Chen Y, Xu X, et al. Clinical characteristics of 24 asymptomatic infections with COVID-19 screened among close contacts in Nanjing, China. Sci China Life Sci. 2020 May;63(5):706-11.

162. Guan Q, Liu M, Zhuang YJ, Yuan Y, Wang SS, Li $\mathrm{J}$, et al. [Epidemiological investigation of a family clustering of COVID-19]. Zhonghua Liu Xing Bing Xue ZaZhi. 2020 May 10;41(5):629-33. Chinese.

163. Qiu YY, Wang SQ, Wang XL, Lu WX, Qiao D, Li $\mathrm{JB}$, et al. [Epidemiological analysis on a family cluster of COVID-19]. Zhonghua Liu Xing Bing Xue Za Zhi. 2020 Apr 10;41(4):506-9. Chinese.

164. Pan X, Chen D, Xia Y, Wu X, Li T, Ou X, et al. Asymptomatic cases in a family cluster with SARS-CoV-2 infection. Lancet Infect Dis. 2020 Apr;20(4):410-1. 
165. Chan JF, Yuan S, Kok KH, To KK, Chu H, Yang $\mathrm{J}$, et al. A familial cluster of pneumonia associated with the 2019 novel coronavirus indicating person-to-person transmission: a study of a family cluster. Lancet. 2020 Feb 15;395(10223):514-23.

166. Yu P, Zhu J, Zhang Z, Han Y. A familial cluster of infection associated with the 2019 novel coronavirus indicating potential person-to-person transmission during the incubation period. J Infect Dis. 2020 May 11;221(11):1757-61.

167. Huang R, Xia J, Chen Y, Shan C, Wu C. A family cluster of SARS-CoV-2 infection involving 11 patients in Nanjing, China. Lancet Infect Dis. 2020 May:20(5):534-5

168. Zou L, Ruan F, Huang M, Liang L, Huang H, Hong $Z$, et al. SARS-CoV-2 viral loading upper respiratory specimens of infected patients. N Engl J Med. 2020 Mar 19;382(12):1177-9.

169. Rothe C, Schunk M, Sothmann P, Bretzel G, Froeschl G, Wallrauch C, et al. Transmission of 2019-nCoV infection from an asymptomatic contact in Germany. N Engl J Med. 2020 Mar 5;382(10):970-1.

170. Heald-Sargent T, Muller WJ, Zheng X, Rippe J, Patel AB, Kociolek LK. Age-related differences in nasopharyngeal severe acute respiratory syndrome Coronavirus 2 (SARS-CoV-2) levels in patients with mild to moderate Coronavirus disease 2019 (COVID-19). JAMA Pediatr. 2020 Jul 30. DOI: 10.1001/jamapediatrics.2020.3651.

171. Park YJ, Choe YJ, Park O, Park SY, Kim YM, Kim J, et al. Contact tracing during Coronavirus disease outbreak, South Korea, 2020. Emerg Infect Dis. 2020 Jul16;26(10). DOI: 10.3201/ eid2610.201315.

172. Park SY, Kim YM, Yi S, Lee S, Na BJ, Kim CB et al. Coronavirus disease outbreaking call center, South Korea. Emerg Infect Dis. 2020 Aug;26(8):1666-70.

173. James A, Eagle L, Phillips C, Hedges DS, Bodenhamer C, Brown R, et al. High COVID-19 Attack Rate Among Attendees at Events at a Church - Arkansas, March 2020. MMWR Morb Mortal Wkly Rep. 2020 May 22;69(20):632-5.

174. Jang S, Han SH, Rhee JY. Cluster of Coronavirus disease associated with fitness dance classes, South Korea. Emerg Infect Dis. 2020 Aug;26(8):1917-20.

175. Hamner L, Dubbel P, Capron I, Ross A, Jordan A, Lee J, et al. High SARS-CoV-2 attack rate following exposure at a choir practice - Skagit County, Washington, March 2020. MMWR Morb Mortal Wkly Rep. 2020 May 15;69(19):606-10.

176. Naserghandi A, Allameh SF, Saffarpour R. All about COVID-19 in brief. New Microbes New Infect. 2020 Apr 13;35:100678. DOI: 10.1016/j. nmni.2020.100678.

177. Jalava K. First respiratory transmitted food borne outbreak? Int J Hyg Environ Health. 2020 May;226:113490.

178. World Health Organization. COVID-19 and food safety: guidance for food businesses [Internet]. Geneva: World Health Organization; 2020 Apr 7 [cited 2020 Apr 30] Available at: https://www.who.int/publications/i/ item/covid-19-and-food-safety-guidance-for -food-businesses

179. Centers for Disease Control and Prevention (CDC) [Internet]. Atlanta: Centers for Disease Control and Prevention (CDC); c2020. Food Safety Newsletters. Food safety and coronavirus disease 2019 (COVID-19); 2020 [cited 2020 Apr 28]. Available at: https://www.cdc.gov/foodsafe ty/newsletter/food-safety-and-Coronavirus.html

180. Centers for Disease Control and Prevention (CDC) [Internet]. Atlanta: Centers for Disease Control and Prevention (CDC); c2020. Frequently Asked Questions. Water; [cited 2020
Apr 30]. Available at: https://www.cdc.gov/ coronavirus/2019-ncov/php/water.html

181. Yu F, Yan L, Wang N, Yang S, Wang L, Tang Y, et al. Quantitative detection andviral load analysis of SARS-CoV-2 in infected patients. Clin Infect Dis. 2020 Jul28;71(15):793-8.

182. Wang XW, Li JS, Jin M, Zhen B, Kong QX, Song $N$, et al. Study on the resistance of severe acute respiratory syndrome-associated coronavirus. J Virol Methods. 2005 Jun;126(12):171-7.

183. Casanova L, Rutala WA, Weber DJ, Sobsey MD. Survival of surrogate coronaviruses in water. Water Res. 2009 Apr;43(7):1893-8.

184. Water Services Association of Australia - COVID-19. SARS-CoV-2 - Water and Sanitation Fact Sheet [Internet]. Adelaide: Water Research Australia; [updated 2020 Mar 5; cited 2020 Apr 30]. 3 p. Available at: https://www.waterra.com au/ r9550/media/system/attrib/file/2200/Water RA_FS_Coronavirus_V11.pdf

185. World Health Organization [Internet]. Geneva: World Health Organization; c2020. Publications. Overview. Water, sanitation, hygiene and waste management for SARS-CoV-2, the virus that causes COVID-19; 2020 Jul 29 [cited 2020 Aug 3]. 11 p. Available at: https://www.who.int/ publications-detail/water-sanitation-hygiene -and-waste-management-for-covid-19

186. La Rosa G, Bonadonna L, Lucentini L, Kenmoe $S$, Suffredini E. Coronavirus in water environments: occurrence, persistence and concentration methods - A scoping review. Water Res. 2020 Jul 15;179:115899. DOI: 10.1016/j. watres.2020.115899.

187. Centers for Disease Control and Prevention (CDC) [Internet]. Atlanta: Centers for Disease Control and pfrevention (CDC); c2020. Coronavirus Disease 2019 (COVID-19). Health Care Workers. Clinical Questions about COVID-19: Questionsand Answers. Waste management; [updated 2020 Aug 4; cited 2020 Apr 30]. Available at: https://www.cdc.gov/coronavirus/2019 -ncov/hcp/faq.html\#Waste-Management

188. Huang YS, Vanlandingham DL, Bilyeu AN, Sharp HM, Hettenbach SM, Higgs S. SARS-CoV-2 failure to infect or replicate in mosquitoes: an extreme challenge. Sci Rep. 2020 Jul 17;10(1):11915. DOI: 10.1038/s41598-020-68882-7.

189. World Health Organization [Internet]. Geneva: World Health Organization; c2020. Coronavirus disease (COVID-19). Advice for the public. Myth busters; [cited 2020 Apr 30]; [about 6 p.]. Available at: https://www.who.int/emergencies/diseases/novel -coronavirus-2019/advice-for-public/myth-busters

190. American Mosquito Control Association [Internet]. Sacramento, CA: American Mosquito Control Association; c2020. News and Press. Can mosquitoes transmit the coronavirus?; $2020 \mathrm{Mar}$ 10 [cited 2020 Apr 30]. Available at: https://www mosquito.org/news/492656/Can-Mosquitoes -Transmit-the-Coronavirus.htm

191. Franchini M, Farrugia A, Velati C, Zanetti A, Romanò L, Grazzini G, et al. The impact of the SARS-CoV-2 outbreak on the safety and availability of blood transfusions in Italy. Vox Sang. 2020 Apr 2. DOI: 10.1111/vox.12928.

192. Chang L, Yan Y, Wang L. Coronavirus disease 2019: coronaviruses and blood safety. Transfus Med Rev. 2020 Apr;34(2):75-80.

193. Dodd RY, Stramer SL. COVID-19 and blood safety: help with a dilemma. Transfus Med Rev. 2020 Apr;34(2):73-4.

194. Heneghan C, Brassey J, Jefferson T. SARSCoV-2 viral load and the severity of COVID-19 [Internet]. Oxford: Centre for Evidence-Based Medicine; 2020 Mar 26 [cited Apr 17]. Available at: https://wwwcebmnet/covid-19/sars-cov-2-vi ral-load-and-the-severity-of-covid-19/
195. Kwon SY, Kim EJ, Jung YS, Jang JS, Cho NS Post-donation COVID-19 identificationin blood donors. Vox Sanguini [Internet]. Amsterdam: International Society of Blood Transmission; 2020 Apr 2 [cited 2020 Apr 17]. Available at: https://onlinelibrary.wiley.com/doi/epdf/10.1111/ vox.12925

196. Cho HJ, Koo JW, Roh SK, Kim YK, Suh JS, Moon $\mathrm{JH}$, et al. COVID-19 transmission and blood transfusion: a case report. J Infect Public Health. 2020 May 13. DOI: 10.1016/j.jiph.2020.05.001.

197. Liu W, Li H. COVID-19: Attacks the 1-beta chain of hemoglobin and captures the porphyrin to inhibit human heme metabolism. chemRxiv [Internet]. New York: Cold Spring Harbor Lab; 2020 Jul 13 [cited 2020 Jul 25]. Available at: https://chemrxiv .org/articles/preprint/COVID19_Disease_ORF8 _and_Surface_Glycoprotein_Inhibit_Heme_Me tabolism by Binding to Porphyrin/11938173

198. Chang L, Zhao L, Gong H, Wang L, Wang L. Severe acute respiratory syndrome coronavirus 2 RNA detected in blood donations. Emerg Infect Dis. 2020 Jul;26(7):1631-3.

199. European Center for Disease Prevention and Control. Outbreak of acute respiratory syndrome associated with a novel Coronavirus, Wuhan, China; first update [Internet]. Stockholm: European Center for Disease Prevention and Control 2020 Jan 22 [cited 2020 May 1]. 12 p. Available at: https://www.ecdc.europa.eu/sites/default/ files/documents/Risk-assessment-pneumonia -Wuhan-China-22-Jan-2020.pdf

200. American Association of Blood Banks. Update: impact of 2019 novel coronavirus and blood safety [Internet]. Maryland: American Association of Blood Banks; 2020 [cited 2020 May 1]. 6 p. Available at: http://www.aabb.org/advocacy/ regulatorygovernment/Documents/Impact-of -2019-Novel-Coronavirus-on-Blood-Donation.pdf

201. The New York Blood Center Enterprises. COVID-19 and Blood Donation [Internet]. New York: New York Blood Center Enterprises; c2020 [cited 2020 May 1]. Available at: https://www.nybc .org/donate-blood/covid-19-and-blood-donation -copyl

202. Michaels MG, La Hoz RM, Danziger-Isakov L, Blumberg EA, Kumar D, Green M, et al. Coronavirus disease 2019: implications of emerging infections for transplantation. Am J Transplant. 2020 Jul;20(7):1768-72

203. Saigal S, Gupta S, Sudhindran S, Goyal N, Rastogi $A$, Jacob $M$, et al. Liver transplantation and COVID-19 (Coronavirus) infection: guidelines of the liver transplant Society of India (LTSI). Hepatol Int. 2020 Jul;14(4):429-31.

204. Bhoori S, Rossi RE, Citterio D, Mazzaferro V. COVID-19 in long-term liver transplant patients: preliminary experience from an Italian transplant centre in Lombardy. Lancet Gastroenterol Hepatol. 2020 Jun;5(6):532-3.

205. Banerjee D, Popoola J, Shah S, Ster IC, Quan V, Phanish M. COVID-19 infection in kidney transplant recipients. Kidney Int. 2020 Jun;97(6):1076-82.

206. Wang R, Liao C, He H, Hu C, Wei Z, Hong Z, et al COVID-19 in hemodialysis patients: a report of 5 cases. Am J Kidney Dis. 2020 Jul;76(1):141-3.

207. Ferrey AJ, Choi G, Hanna RM, Chang Y, Tantisattamo $\mathrm{E}$, Ivaturi $\mathrm{K}$, et al. A case of novel Coronavirus disease 19 in a chronic hemodialysis patient presenting with gastroenteritis and developing severe pulmonary disease. Am J Nephrol. 2020;51(5):337-42.

208. American Society of Nephrology. Information for screening and management of COVID-19 in the outpatient dialysis facility [Internet]. Washington, D.C.: American Society of Nephrology; 2020 Ma 13 [cited 2020 Apr 30]. 7 p. Available at: https:// www.asn-online.org/g/blast/files/DIALYSIS CO VID_2019_Update_03.13.2020_FINAL.pdf 
209. Centers for Disease Control and Prevention (CDC). Atlanta: Centers or Disease Control and Prevention (CDC); c2020. Coronavirus Disease (COVID-19). Healthcare Workers. Considerations for providing hemodialysis to patients with suspected or confirmed COVID-19 in acute care settings; [updated $2020 \mathrm{Jul}$ 7; cited 2020 Apr 30]. Available at: https://www.cdc.gov/ coronavirus/2019-ncov/hcp/dialysis/dialysis-in -acute-care.html

210. Ikizler TA, Kliger AS. Minimizing the risk of COVID-19 among patients on dialysis. Nat Rev Nephrol. 2020 Jun;16(6):311-3.

211. Weiner DE, Watnick SG. Hemodialysis and COVID-19: an Achilles' heeling the pandemic health care response in the United States. Kidney Med. 2020 May-Jun;2(3):227-30.

212. Kliger AS, Silberzweig J. Mitigating risk of COVID-19 in dialysis facilities. Clin J Am Soc Nephrol. 2020 May 7;15(5):707-9.

213. Wang D, Hu B, Hu C, Zhu F, Liu X, Zhang J, et al. Clinical characteristics of 138 hospitalized patients with 2019 novel coronavirus-infected pneumonia in Wuhan,China. JAMA. 2020 Feb 7. DOI: 10.1001/jama.2020.1585

214. Jiang WY, Xiong R, Lu ZL. Clinical practice of prevention and treatment of novel Coronavirus infection in the medical personnel and surgical patients in the Department of Thoracic Surgery of Hospitals in Wuhan. Chin J Thoracic Cardiovasc Surg. 2020;27:364-70.

215. Cao G, Tang S, Yang D, Shi W, Wang X, Wang $\mathrm{H}$, et al. One nosocomial cluster following with a familial cluster of COVID-19 cases: the potential transmission risk inpatients with negative swab tests [Internet]. North Carolina: Res Square; 2020 May 29 [cited 2020 Jul 20].15 p. Available at: https://www.researchsquare.com/article/rs $-17879 / v 1$

216. Wang Q, Kuang W, Ping W. Prevention and treatment of cross infection of novel Coronavirus pneumonia in thoracic surgery ward. Chin J Thoracic Cardiovasc Surg. 2020;27:371-5.

217. Zhou Q, Gao Y, Wang X, Liu R, Du P, Wang X, et al. Nosocomial infections among patients with COVID-19, SARS and MERS: a rapid review and meta-analysis. medRxiv[Internet]. New York: Cold Spring Harbor Lab; 2020 Apr 17 [cited 2020 Apr 25]. Available at: https://www.medrxiv.org/ content/10.1101/2020.04.14.20065730v1

218. Wee LE, Conceicao EP, Sim XYJ, Aung MK, Tan $\mathrm{KY}$, et al. Minimising intra-hospital transmission of COVID-19: the role of social distancing. J Hosp Infect. 2020 Jun;105(2):113-5.

219. Wong SCY, Kwong RTS, Wu TC, Chan JWM, Chu MY, Lee SY, et al. Risk of nosocomial transmission of coronavirus disease 2019: an experience in a general ward setting in Hong Kong. J Hosp Infect. 2020 Jun;105(2):119-27.

220. Wang L, Chen X, Ye L. Integrated infection control strategy to minimize nosocomial infection during outbreak of COVID-19 among ED healthcare workers. J Emerg Nursing. 2020 Jul:46(4):424-5.

221. Klompas M. Coronavirus disease 2019 (COVID-19): protecting hospitals from the invisible. Ann Intern Med. 2020 May 5;172(9):619-20.

222. Simonds A, Hanak A, Chatwin M, Morrell M, Hall $\mathrm{A}$, Parker $\mathrm{KH}$, et al. Evaluation of droplet dispersion during non-invasive ventilation, oxygen therapy, nebuliser treatment and chest physiotherapy in clinical practice: implications for management of pandemic influenza and other airborne infections. Health Technol Assess. 2010 Oct;14(46):131-72.

223. Hui D, Chan M, Chow B. Aerosol dispersion during various respiratory therapies: a risk assessment model of nosocomial infection to health care workers. Hong Kong Med J. 2014 Aug;20 Suppl 4:9-13.
224. Cabrini L, Landoni G, Zangrillo A. Minimise nosocomial spread of 2019-nCoV when treating acute respiratory failure. Lancet. $2020 \mathrm{Feb}$ 29;395(10225):685. DOI: 10.1016/S01406736(20)30359-7.

225. Chen X, Tian J, Li G, Li G. Initiation of a new infection control system for the COVID-19 outbreak. Lancet Infect Dis. 2020 Apr;20(4):397-8.

226. Peng J, Ren N, Wang M, Zhang G. Practical experiences and suggestions for the 'eagle-eyed observer': a novel promising role for controlling nosocomial infection in the COVID-19 outbreak. J Hosp Infect. 2020 May;105(1):106-7.

227. Varia M, Wilson S, Sarwal S, McGeer A, Gournis E, Galanis E. Investigation of a nosocomia outbreak of severe acute respiratory syndrome (SARS) in Toronto, Canada. CMAJ. 2003 Aug 19;169(4):285-92.

228. Lee $N$, Hui $D$, Wu $A$, Chan $P$, Cameron $P$, Joynt $\mathrm{GM}$, et al. A major outbreak ofsevere acute respiratory syndrome in Hong Kong. $\mathrm{N}$ Engl J Med. 2003 May 15;348(20):1986-94.

229. Hunter E, Price DA, Murphy E, van der Loeff IS, Baker KF, Lendrem D, et al. First experience of COVID-19 screening of health-care workers in England. Lancet. 2020 May 2;395(10234):e77-e8.

230. Liu M, He P, Liu HG, Wang XJ, Li FJ, Chen $\mathrm{S}$, et al. [Clinical characteristics of 30 medical workers infected with new coronavirus pneumonia]. Zhonghua Jie $\mathrm{He} \mathrm{He} \mathrm{HuXi} \mathrm{Za}$ Zhi. 2020 Feb 17;43:E016. DOI: 10.3760/ cma.j.issn.1001-0939.2020.0016. Chinese.

231. Zhan M, Qin $Y$, Xue X, Zhu S. Death from Covid-19 of 23 health care workers in China. N Engl J Med. 2020 Jun 4;382(23):2267-8.

232. Ran L, Chen X, Wang Y, Wu W, Zhang L, Tan X. Risk factors of healthcare workers with corona virus disease 2019: a retrospective cohort study in a designated hospital of Wuhan in China. Clin Infect Dis. 2020 Mar 17. pii: ciaa287. DOI: 10.1093/cid/ciaa287.

233. Ng K, Poon BH, Kiat Puar TH, Shan Quah JL, Loh WJ, Wong YJ, et al. COVID-19 and the risk to health care workers: a case report. Ann Intern Med. 2020 Jun 2:172(11):766-7.

234. COVID-19: protecting health-care workers. Lancet. 2020 Mar 21;395(10228):922

235. World Health Organization [Internet]. Copenhagen: World Health Organization Regional Office for Europe; c2020. Newsroom. Detail. Shortage of personal protective equipment endangering health workers worldwide; 2020 Mar 3 [cited 2020 Apr 27]. Available at: https://www.who.int/ news-room/detail/03-03-2020-shortage-of-per sonal-protective-equipment-endangering-health -workers-worldwide

236. Cheng VC, Wong SC, Yuen KY. Estimating Coronavirus disease 2019 infection risk in health care workers. JAMA Netw Open. 2020 May 1;3(5):e209687. DOI: 10.1001/jamanetworkopen.2020.9687.

237. Kluytmans-van den Bergh MFQ, Buiting AGM, Pas SD, Bentvelsen RG, van denBijllaardt W, van Oudheusden AJG, et al. Prevalence and clinical presentation of health care workers with symptoms of Coronavirus disease 2019 in 2 Dutchhospitals during an early phase of the pandemic. JAMA Netw Open. 2020 May 1;3(5):e209673. DOI: 10.1001/jamanetworkopen.2020.9673.

238. Iken $\mathrm{O}$, Abakporo $\mathrm{U}$, Ayobami O, Attoye $\mathrm{T}$. COVID-19: Travel health and the implications for sub -Saharan Africa. Travel Med Infect Dis 2020 May-Jun;35:101645. DOI: 10.1016/j. tmaid.2020.101645

239. World Health Organization [Internet]. Geneva: World Health Organization; c2020. Publication. Overview. Interim guidance: management of ill travellers atpoints of entry-international airports, ports and ground crossings-in the context ofthe COVID-19 outbreak; 2020 Mar 19 [cited 2020 Apr 27]. Available at: https://www.who .int/publications/i/item/10665-331512

240. World Health Organization [Internet]. Geneva: World Health Organization; c2020. Newsroom. Article. Updated WHO recommendations for international traffic in relation to COVID-19 outbreak; 2020 Feb 29 [cited 2020 Apr 27]. Available at: https://www.who.int/news-room/articles-detail/ updated-who-recommendations-for-internation al-traffic-in-relation-to-covid-19-outbreak

241. Zhong P, Guo S, Chen T. Correlation between travellers departing from Wuhan before the Spring Festival and subsequent spread of COVID-19 to all provinces in China. J Travel Med. 2020 May 18;27(3). pii: taaa036. DOI: 10.1093/ jtm/taaa036

242. Zhao S, Zhuang Z, Cao P, Ran J, Gao D, Lou $Y$, et al. Quantifying the association between domestic travel and the exportation of novel coronavirus (2019-nCoV) cases from Wuhan, China in 2020: a correlational analysis. J Travel Med. 2020 Mar 13;27(2). pii: taaa022. DOI: 10.1093/jtm/taaa022.

243. Devi S. Travel restrictions hampering COVID-19 response. Lancet. 2020 Apr 25;395(10233):1331-2.

244. Ng O-T, Marimuthu K, Chia PY, Koh V, Chiew CJ, De Wang $L$, et al. SARS-CoV-2 infection among travelers returning from Wuhan, China. N Engl J Med. 2020 Apr 9;382(15):1476-8.

245. Kuan MM, Lin T, Chuang JH, Wu HS. Epidemiological trends and the effect of airport fever screening on prevention of domestic dengue fever outbreaks in Taiwan,1998-2007. Int J Infect Dis. 2010 Aug;14(8):e693-e7

246. Thwaites GE, Day NP. Approach to fever in the returning traveler. N Engl J Med. 2017 Feb 9;376(6):548-60.

247. Backer JA, Klinkenberg D, Wallinga J. Incubation period of 2019 novel coronavirus (2019nCoV) infections among travellers from Wuhan, China, 20-28 January 2020. Euro Surveill. 2020 Feb;25(5). DOI: 10.2807/1560-7917. ES.2020.25.5.2000062

248. Okada $P$, Buathong $R$, Phuygun $S$, Thanadachakul T, Parnmen S, Wongboot W, et al. Early transmission patterns of coronavirus disease 2019 (COVID-19) in travellers from Wuhan to Thailand, January 2020. Euro Surveill. 2020 Feb;25(8). DOI: 10.2807/1560-7917. ES.2020.25.8.2000097.

249. Hoehl S, Rabenau H, Berger A, Kortenbusch $M$, Cinatl J, Bojkova D, et al. Evidence of SARS-CoV-2 Infection in Returning Travelers from Wuhan, China. N Engl J Med. 2020 Mar 26;382(13):1278-80.

250. Samaan G, Patel M, Spencer J, Roberts L. Border screening for SARS in Australia: what has been learnt? Med J Aust. 2004 Mar 1;180(5):220-3.

251. Quilty BJ, Clifford S, Flasche S, Eggo RM; CMMID nCoV working group. Effectiveness of airport screening at detecting travellers infected with novel coronavirus (2019-nCoV). Euro Surveill. 2020 Feb;25(5). DOI: 10.2807/1560-7917. ES.2020.25.5.2000080

252. Bwire GM, Paulo LS. Coronavirus disease-2019: is fever an adequate screening for the returning travelers? Trop Med Health. 2020 Mar 9;48:14.

253. Anzai A, Kobayashi T, Linton NM, Kinoshita R, Hayashi K, Suzuki A, et al. Assessing the impact of reduced travel on exportation dynamics of novel coronavirus infection (COVID-19). J Clin Med. 2020 Feb 24;9(2). pii: E601.DOI: 10.3390/ jcm9020601.

254. Chinazzi M, Davis JT, Ajelli M, Gioannini C, Litvinova M, Merler S, et al. The effect of trave restrictions on the spread of the 2019 novel coronavirus (COVID-19) outbreak. Science. 2020 Apr 24;368(6489):395-400. 
255. Karami M, Doosti-Irani A, Ardalan A, GohariEnsaf $F$, Berangi $Z$, Massad $E$, et al. Public health threats in mass gatherings: asystematic review. Disaster Med Public Health Prep. 2019 Dec;13(5-6):1035-46.

256. Memish ZA, Steffen R, White P, Dar O, Azhar El, Sharma A, et al. Mass gatherings medicine: public health issues arising from mass gathering religious and sporting events. Lancet. 2019 May 18;393(10185):2073-84.

257. Ebrahim SH, Memish ZA. COVID-19 - the role of mass gatherings. Travel Med Infect Dis. 2020 Mar-Apr;34:101617. DOI: 10.1016/j. tmaid.2020.101617.

258. McCloskey B, Zumla A, Ippolito G, Blumberg L, Arbon $\mathrm{P}$, Cicero A, et al. Mass gathering events and reducing further global spread of COVID-19: a political and public health dilemma. Lancet. 2020 Apr 4;395(10230):1096-9.

259. Petersen E, Memish ZA, Zumla A, Maani AA. Transmission of respiratory tract infections at mass gathering events. Curr Opin Pulm Med. 2020 May;26(3):197-202.

260. Lai CC, Shih TP, Ko WC, Tang HJ, Hsueh PR. Severe acute respiratory syndrome coronavirus 2 (SARS-CoV-2) and coronavirus disease-2019 (COVID-19): the epidemic and the challenges. Int J Antimicrob Agents. 2020 Mar;55(3). DOI:10.1016/j.ijantimicag.2020.105924

261. Nunan D, Brassey J. What is the evidence for mass gatherings during global pandemics? A rapid summary of best-available evidence [Internet]. Oxford: Center for Evidene-Based Medicine (CEBM); 2020 Mar 20 [cited 2020 May 4]. Available at: https://www.cebm.net/covid-19/ what-is-the-evidence-for-mass-gatherings-during-global-pandemics/

262. Centers for Disease Control and Prevention (CDC) [Internet]. Atlanta: Centers for Disease Control and Prevention (CDC); c2020. Coronavirus disease (COVID-19). Community, Work and Schools. Gatherings and Community Events: plan, prepare and respond; 2020 Jun 12 [cited 2020 Apr 28]. Available at: https://www.cdc. gov/coronavirus/2019-ncov/community/largeevents/index.html

263. World Health Organization. Interim guidance: Key planning recommendations form as gatherings in the context of the current COVID-19 outbreak [Internet]. Geneva: World Health Organization; 2020 [cited 2020 Apr 30]. Available at: https://apps.who.int/ iris/bitstream/handle/10665/331004/WHO2019-nCoV-POEmassgathering-2020.1 -eng.pdf?sequence $=1$ \&isAllowed $=y$

264. Centers for Disease Control and Prevention (CDC) [Internet]. Atlanta:Centers for Disease Control and Prevention (CDC); c2020. Coronavirus disease (COVID-19). Get Your Mass Gatherings or Large Community Events Ready; 2020 [cited 2020 Apr 28]. Available at: https:// www.cdc.gov/coronavirus/2019-ncov/commu nity/large-events/mass-gatherings-ready-for -covid-19.htm

265. World Health Organization [Internet]. Geneva: World Health Organization; c2020.Q\&A on Mass Gatherings and COVID-19; 2020 [cited 2020 Apr 30]. Available at: https://www.who.int/news-room/qa-detail/q-a-on-mass-gatherings-and-covid-19

266. Rodríguez-Morales AJ, Gallego V, EscaleraAntezana JP, Mendez CA, Zambrano LI, FrancoParedes C, et al. COVID-19 in Latin America: the implications of the first confirmed case in Brazil. Travel Med Infect Dis. 2020 May-Jun;35:101613. DOI: 10.1016/j.tmaid.2020.101613

267. Kluge HHP, Jakab Z, Bartovic J, D'Anna V, Severoni S. Refugee and migrant health in the COVID-19 response. Lancet. $2020 \mathrm{Apr}$ 18;395(10232):1237-9.
268. COVID-19 will not leave behind refugees and migrants. Lancet. 2020 Apr 4;395(10230):1090.

269. World Health Organization Regional Office for Europe [Internet]. Geneva: World Health Organization; c2020. Health Topics. COVID-19: ensuring refugees and migrants are not left behind 2020 Apr 16 [cited 2020 Apr 27]. Available at: http://www.euro.who.int/en/health-topics/ health-determinants/migration-and-health/news/ news/2020/4/covid-19-ensuring-refugees-and -migrants-are-not-left-behind

270. World Health Organization Regional Office for Europe [Internet]. Interim guidance for refugee and migrant health in relation to COVID-19 in the WHO European Region Geneva: World Health Organization; 2020 Mar 25 [cited 2020 Apr 27]. Available at: http://www.euro .who.int/en/health-topics/health-determinants/ migration-and-health/publications/2020/ interim-guidance-for-refugee-and-migrant -health-in-relation-to-covid-19-in-the-who-euro pean-region-2020

271. Tsai J, Wilson M. COVID-19: a potential public health problem for homeless populations. Lancet Public Health. 2020 Apr;5(4):e186-e7.

272. Baggett TP, Hwang SW, O'Connell JJ, Porneala $B C$, Stringfellow EJ, Orav EJ, et al. Mortality among homeless adults in Boston: shifts in causes of death over a 15-year period. JAMA Intern Med. 2013 Feb 11;173(3):189-95.

273. Lima NNR, de Souza RI, Feitosa PWG Moreira JLS, da Silva CGL, Neto MLR. People experiencing homelessness: their potential exposure to COVID-19. Psychiatry Res. 2020 Apr 11;288:112945. DOI: 10.1016/j.psychres.2020.112945

274. Leung CS, Ho MM, Kiss A, Gundlapalli AV, Hwang SW. Homelessness and the response to emerging infectious disease outbreaks: lessons from SARS. J Urban Health. 2008 May;85(3):402-10.

275. Centers for Disease Control and Prevention (CDC) [Internet]. Atlanta: Centers for Disease Control and Prevention (CDC); c2020. Coronavirus Disease 2019 (COVID-19). Community, Work and School. Interim Guidance for Homeless Service Providers to Plan and Respond to Coronavirus Disease 2019 (COVID-19); 2020 Aug 5 [cited 2020 Apr 28]. Available at: https://www.cdc.gov/ coronavirus/2019-ncov/community/homeless -shelters/plan-prepare-respond.htm

276. National Institute of Drug Abuse [Internet]. Maryland: National Institute of Drug Abuse; c2020. Nora's blog. COVID-19: Potential implications for individuals with substance use disorders; 2020 Apr 6 [cited 2020 Apr 28]; [about 8 p.]. Available at: https://www.drugabuse.gov/about-nida/noras -blog/2020/04/covid-19-potential-implications -individuals-substance-use-disorders

277. Farhoudian A, Baldacchino A, Clark N, Gerra G, Ekhtiari H, Dom G, et al. COVID-19 and substance use disorders: recommendations to a comprehensive healthcare response. An International Society of Addiction Medicine (ISAM) Practice and Policy Interest Group Position Paper. Basic Clin Neurosci. 2020 MarApr;11(2):133-46.

278. Volkow ND. Collision of the COVID-19 and addiction epidemics. Ann Inter Med. 2020 Jul 7;173(1):61-2.

279. Cai H. Sex difference and smoking predisposition in patients with COVID-19. Lancet Respir Med. 2020 Apr;8(4):e20. DOI: 10.1016/ S2213-2600(20)30117-X

280. Cai G. Bulk and single-cell transcriptomics identify tobacco-use disparity in lung gene expression of ACE2, the receptor of 2019-nCov. medRxiv [Internet]. New York: Cold Spring Harbor Lab; 2020 Feb 28 [cited 2020 Apr 25]. Avail- able at: https://www.medrxiv.org/content/10.110 1/2020.02.05.20020107v3

281. Leung JM, Yang CX, Tam A, Shaipanich T, Hackett TL, Singhera GK, et al. ACE-2 expression in the small airway epithelia of smokers and COPD patients: implications for COVID-19. Eur Respir J. 2020 May 14;55(5). pii: 2000688. DOI 10.1183/13993003.00688-2020.

282. Vardavas $\mathrm{Cl}$, Nikitara K. COVID-19 and smoking: a systematic review of the evidence. Tob Induc Dis. 2020 Mar 20;18:20. DOI: 10.18332/tid/119324.

283. Zhao Q, Meng M, Kumar R, Wu Y, Huang J, Lian N, et al. The impact of COPD and smoking history on the severity of Covid-19: a systemic review and meta-analysis. J Med Virol. $2020 \mathrm{Apr}$ 15. DOI: 10.1002/jmv.25889.

284. Rossato M, Russo L, Mazzocut S, Di Vincenzo A, Fioretto P, Vettor R. Current smok ing is not associated with COVID-19. Eur Respir J. 2020 Jun 4;55(6). pii:2001290. DOI: 10.1183/13993003.01290-2020.

285. Farsalinos K, Barbouni A, Niaura R. Smoking, vaping and hospitalization for COVID-19 [Internet]. London: Qeios; 2020 Apr 4 [cited 2020 May 25]. Available at: https://www.qeios .com/read/Z69O8A.13

286. Guan WJ, Liang WH, Zhao Y, Liang HR, Chen ZS, Li YM, et al. Comorbidity and its impact on 1590 patients with Covid-19 in China: a nationwide analysis. Eur Respir J. Eur Respir J. 2020 May 14;55(5). pii: 2000547. DOI 10.1183/13993003.00547-2020.

287. Emami A, Javanmardi $F$, Pirbonyeh N, Akbar A. Prevalence of underlying diseases in hospitalized patients with COVID-19: a systematic review and meta-analysis. Arch Acad Emerg Med. 2020 Mar 24;8(1):e35. PMID: 32232218.

288. Miyara M, Tubach F, Pourcher V, Morelot-Panzini C, Pernet J, Haroche J, et al. Low incidence of daily active tobacco smoking in patients with symptomatic COVID-19 [Internet]. London: Qeios; 2020 Apr 21 [cited 2020 May 25]. Available at: https://www.qeios.com/read/WPP19W.3

289. Changeux JP, Amoura Z, Rey F, Miyara M. A nicotinic hypothesis for Covid-19 with preventive nd therapeutic implications [Internet]. London: Qeios; 2020 Apr 21 [cited 2020 May 20]. Available at: https://www.qeios.com/read/FXGQSB

290. World Health Organization [Internet]. Geneva: World Health Organization; c2020. Q\&A on smoking and COVID-19; 2020 May 27 [cited 2020 Apr 27]. Available at: https://www.who.int/news -room/q-a-detail/q-a-on-smoking-and-covid-19

291. Wu Z, McGoogan JM. Characteristics of and important lessons from the Coronavirus disease 2019 (COVID-19) outbreak in China: summary of a report of 72314 cases from the Chinese center for disease control and prevention. JAMA 2020 Feb 24. DOI: 10.1001/jama.2020.2648.

292. World Health Organization [Internet]. Geneva: World Health Organization; c2020. Tobacco Free Initiative. Know the Truth. Tobacco and waterpipe use increases the risk of suffering from COVID-19; 2020 [cited 2020 Apr 27]. Available at: http://www.emro.who.int/tfi/know-the-truth/ tobacco-and-waterpipe-users-are-at-increased -risk-of-covid-19-infection.html

293. Madison MC, Landers CT, Gu BH, Chang CY, Tung HY, You R, et al. Electronic cigarettes disrupt lung lipid homeostasis and innate immunity independent of nicotine. J Clin Invest. 2019 Oct 1;129(10):4290-304

294. Simooya OO. Infections in prison in low and middle income countries: prevalence and prevention strategies. Open Infect Dis J. 2010;4:33-7.

295. Fazel S, Baillargeon J. The health of prisoners. Lancet. 2011 Mar12;377(9769):956-65.

296. Kinner SA, Young JT, Snow K, Southalan L, López-Acuña D, Ferreira-Borges C, et al. Pris- 
ons and custodial settings are part of a comprehensive response to COVID-19. Lancet Public Health. 2020 Apr;5(4):e188-e9.

297. Hawks L, Woolhandler S, McCormick D. COVID-19 in prisons and jails in the United States. JAMA Intern Med. 2020 Apr 28. DOI: 10.1001/ jamainternmed.2020.1856.

298. Walmsley R. World Prison Population List. 12th ed [Internet]. London: Institute for Criminal Policy Research, University of London; 2018 Sep [cited 2020 May 4].19 p. Available at: https://www.prison studies.org/sites/default/files/resources/down loads/wppl_12.pdf

299. Yang H, Thompson JR. Fighting covid-19 outbreaks in prisons. BMJ. 2020;369:m1362.

300. Centers for Disease Control and Prevention (CDC) [Internet]. Atlanta: Centers for Disease Control and Prevention (CDC); c2020. Coronavirus disease (COVID-19). Your Health.People who are at higher risk for severe illness; [updated 2020 Jun 25; cited 2020 Apr 28]. Available at: https://www.cdc.gov/coronavirus/2019-ncov/ need-extra-precautions/people-at-higher-risk .html

301. World Health Organization. Preparedness, prevention and control of COVID-19 inprisons and places of detention [Internet]. Copenhagen: World Health Organization Regional Office for Europe; 2020 Mar 15 [cited 2020 Apr 27]. 31 p. Available at: http://www.euro.who.int/_data/assets/pdf_file /0019/434026/Preparedness-prevention-and-con trol-of-COVID-19-in-prisons.pdf

\section{THE AUTHORS}

Ekram W. Abd El-Wahab (Corresponding author: ekram.wassim@alexu.edu.eg), assistant professor of tropical health with a master's degree in public health and a doctorate in molecular and cellular biology. Tropical Health Department, Division of Tropical Health, High Institute of Public Health, Alexandria University, Alexandria, Egypt. https://orcid.org/0000-0003 $-4220-5859$

Safaa M. Eassa, professor of parasitology and medical entomology with a master's and doctorate degrees in public health (parasitology and medical entomology). Tropical Health Department, Division of Parasitology and Medical Entomology, High Institute of Public Health, Alexandria University, Alexandria, Egypt. https:// orcid.org/0000-0001-9185-9141

Mohammed Metwally, consultant physician specializing in internal medicine, infectious and endemic diseases with a master's and doctorate degrees in internal medicine. Department of Endemic and Infectious Diseases, Alexandria Fever Hospital, Ministry of Health and Population, Alexandria, Egypt. https://orcid.org/0000 -0002-3341-7879
Husam Al-Hraishawi, lecturer, with a master's degree in veterinary medicine and physiology. Department of Physiology, College of Medicine, Misan University, Amarah-Maysan, Iraq. Researcher, Department of Medicine, Rutgers Cancer Institute of New Jersey, Rutgers University, USA. https://orcid.org/0000-0003-4169-1824

Sherif R. Omar, assistant professor of tropical health with master's and doctoral degrees in public health (tropical health), and a diploma in tropical medicine and hygiene. Tropical Health Department (Division of Tropical Health), High Institute of Public Health, Alexandria University, Alexandria, Egypt. https://orcid.org/0000-0002 $-9808-8412$

\section{DATA AVAILABILITY}

All data are fully available without restriction by the corresponding author at ekram.wassim@ alexu.edu.eg

Submitted: June 26, 2020

Approved for Publication: September 9, 2020 Disclosures: None 